\title{
Prediction of COVID-19 Cases from the Nexus of Air Quality and Meteorological Phenomena: Bangladesh Perspective
}

\author{
Mim Mashrur Ahmed ${ }^{1} \cdot$ Md. Emdadul Hoque ${ }^{1}$ (D) Shahanaj Rahman ${ }^{2} \cdot$ Proshanta Kumar Roy $^{2} \cdot$ Firoz Alam $^{3}$. \\ Muhammad Mustafizur Rahman ${ }^{4}$. Md. Mostafizur Rahman ${ }^{5} \cdot$ Philip K. Hopke ${ }^{6,7}$
}

Received: 13 July 2021 / Revised: 13 October 2021 / Accepted: 9 November 2021 / Published online: 28 November 2021

○ King Abdulaziz University and Springer Nature Switzerland AG 2021

\begin{abstract}
An integrated approach was used to estimate the number of COVID-19 patients related to air quality and meteorological phenomena. Additionally, the air quality during pre-lockdown, lockdown, and post-lockdown stages of the COVID-19 pandemic was assessed to determine the effect of the infection containment measures taken in Bangladesh during the pandemic. The air quality was assessed based on measurements of nitrogen dioxide $\left(\mathrm{NO}_{2}\right)$, sulfur dioxide $\left(\mathrm{SO}_{2}\right)$, ozone $\left(\mathrm{O}_{3}\right)$, carbon monoxide (CO), black carbon, particulate matter $\left(\mathrm{PM}_{2.5}\right.$ and $\left.\mathrm{PM}_{10}\right)$, and aerosol optical depth. Time-averaged maps of these parameters have been generated from NASA's (National Aeronautics and Space Administration) website. Values of these parameters have also been collected from a continuous air monitoring station (CAMS) located in Bangladesh's north-western city Rajshahi. The comparison shows that lockdown during the pandemic has brought significant improvements in air quality. However, the improvement was not sustained, since rapid increases in the air pollutant concentrations were observed in the post-lockdown period. Furthermore, Pearson correlation coefficients between each air quality variable and the daily new COVID-19 case rates were calculated. Different meteorological variables during the same time periods were determined to observe the variation in Rajshahi city. Relationships of these variables with the case rates were also established. Additionally, statistical analyses of the obtained data have been conducted for the measured variables using the Kruskal-Wallis test to assess the differences in the observed data among the pre-lockdown, lockdown, and post-lockdown periods. Dunn's "Q" test was employed to test if the variables showed significance statistical difference during the Kruskal-Wallis test for pairwise comparisons. From the study, it has been observed that both meteorological variables and air quality parameters have significant relationship with daily new COVID-19 case rates. Both positive and negative associations of these parameters with the COVID-19 case rates have been observed. Very high air pollution has been observed in the post-lockdown period. Thus, it is recommended that appropriate authorities undertake corrective measures to protect the environment in cities with large populations. This study provides guidance for decision makers and health officials for future research and potentially reducing the spread of COVID-19.
\end{abstract}

Keywords COVID-19 $\cdot$ Lockdown $\cdot$ Statistical analysis $\cdot$ Meteorological variable $\cdot$ Time-averaged map $\cdot$ CAMS

Md. Emdadul Hoque

mehoque@me.ruet.ac.bd

1 Department of Mechanical Engineering, Rajshahi University of Engineering \& Technology, Rajshahi, Bangladesh

2 Department of Environment, Ministry of Environment, Forests and Climate Change, Dhaka, Bangladesh

3 School of Engineering, RMIT University, Melbourne, Australia

4 Department of Mechanical Engineering, Wichita State University, Wichita, KS, USA
5 Institute for Future Transport and Cities, School of Mechanical, Aerospace and Automotive Engineering, Coventry University, Coventry, UK

6 Department of Public Health Sciences, University of Rochester School of Medicine and Dentistry, Rochester, NY, USA

7 Institute for a Sustainable Environment, Clarkson University, Potsdam, NY, USA 


\section{Introduction}

The COVID-19 pandemic has affected life around the world beginning in December 2019, when it was first reported in China (Gautam 2020; Metya et al. 2020). It was declared as global pandemic on March 2020 by World Health Organization (WHO) (WHO 2020). WHO reported that confirmed cases were maximal in the Americas (44\%) and minimal in Western Pacific (1\%). About $12 \%$ cases are distributed throughout South-East Asia (WHO 2021). Both developed and under-developed countries are facing numerous challenges while dealing with the pandemic. The first COVID-19 case was identified in Bangladesh on March 7, 2020 (Hossain et al. 2020; Shammi et al. 2021). From then on, the pandemic spread exponentially compelling the government to implement a nationwide lockdown beginning on March 26, 2020 (Shammi et al. 2021). Armed forces were deployed to ensure a full lockdown from 24 March 2020 (Akanda and Ahmed 2020). The total confirmed cases in Bangladesh were 1,353,695 and total number of deaths was 22,652 as of 8 August 2021 (Worldometer 2021). Due to the containment actions taken by the government, daily new COVID-19 cases decreased in January and February 2021. However, due to the lack of COVID-19 awareness to maintain social distancing and new viral variants especially the delta variant, daily confirmed cases have started to increase at an alarming rate (IEDCR 2021). Figure 1 illustrates the number of daily confirmed cases, laboratory tests, and case rates (ratio of confirmed cases to the laboratory tests) during April-May 2021 (DGHS 2021).

The city of Rajshahi is one of the six divisional cities of Bangladesh. It is also called the city of education, since a large number of higher education institutions, civil and military administrative units, and installations are located in this central western Bangladesh city. It has a population around 1 million. The city is well connected with the rest of Bangladesh by road, rail, and air. There are also large industrial units located in this city. Therefore, apart from socio-economic activities, environmental conditions have also been greatly influenced by the various containment actions taken by the government during the pandemic. The most affected regions were first identified and named as red zones. Strict lockdowns were maintained in those regions. All mass gatherings were prohibited during the lockdown period. Both intradistrict and interdistrict transportation was halted except for emergency transportation. Financial aid worth of BDT 1.04 trillion was offered to homeless and poor people (Akanda and Ahmed 2020). Various social-awareness messages were circulated through online platforms and newspapers. Currently, 117 centers are performing COVID-19 tests among which only one is situated in Rajshahi (Rajshahi Medical College Hospital (Corona_Info_Bangladesh 2021). According to the recent report aired on 5 August 2021, 1,154,243 people have recovered from the disease and 146,509 people were in isolation (Corona_Info_Bangladesh 2021).

The virus outbreak has intensely affected the world economy as well as different environmental aspects (Bherwani et al. 2021; Lai et al. 2020; Mostafa et al. 2021; Sohrabi et al. 2020). Different factors affected by this pandemic include air quality, municipal and medical waste generation, noise, ground and river water quality, etc. (Zambrano-Monserrate et al. 2020). Air pollution is currently a major global concern including Bangladesh. Different lung diseases are the result of excessive air pollution. A survey in 2011 by Mahmood revealed that on average. 15,000 people die every year due to lung diseases caused by excessive air pollution in Bangladesh (Mahmood 2011). Particulate matter
Fig. 1 Daily lab tests, confirmed cases, and case rates in recent 30 days (06 April 2021-06 May 2021) in Bangladesh

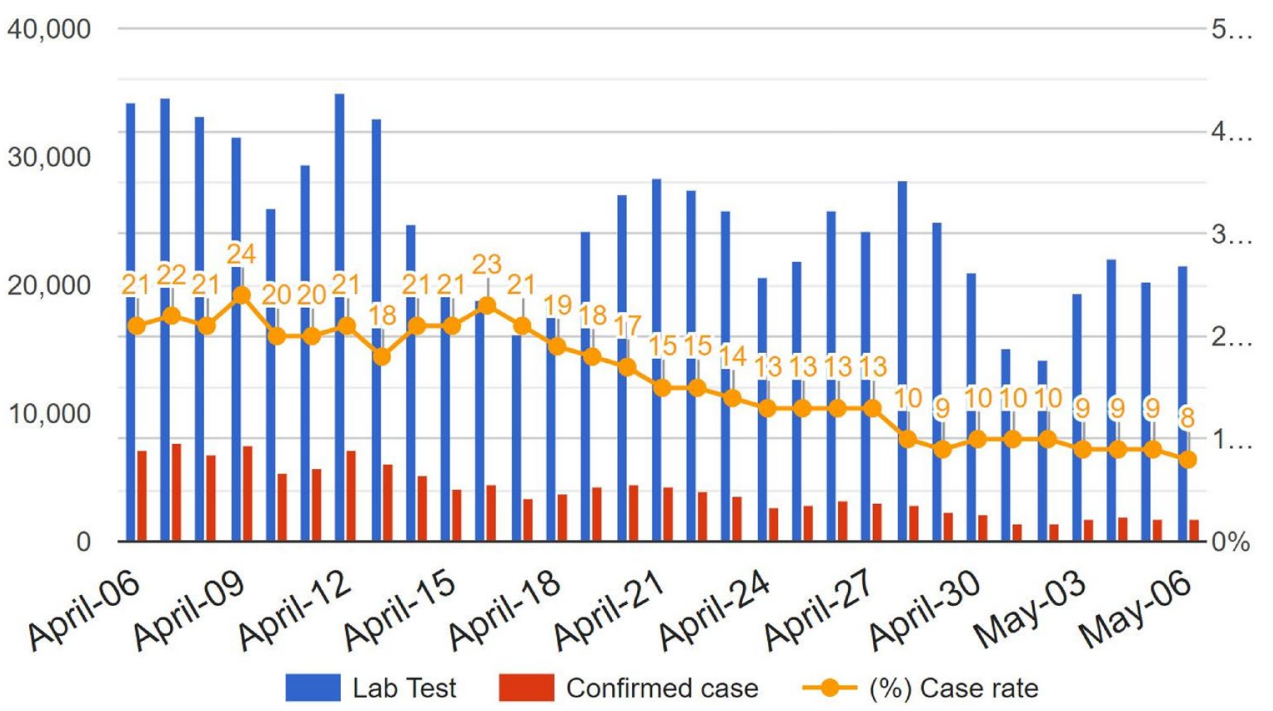


(PM), sulfur dioxide $\left(\mathrm{SO}_{2}\right)$, carbon monoxide (CO), nitrogen dioxide $\left(\mathrm{NO}_{2}\right)$, and ozone $\left(\mathrm{O}_{3}\right)$ are the main pollutants of troposphere that are hazardous to human health (Islam et al. 2021b; Mostafa et al. 2021). Concentration of $\mathrm{NO}_{2}$ increases in the atmosphere from the automotive exhausts, soil emission, biomass burning, incomplete hydrocarbon fuel combustion, etc. (Cheng et al. 2012; Richter and Burrows 2002). $\mathrm{NO}_{2}$ undergoes a complex set of reaction with volatile organic compound (VOC) under sunlight to form tropospheric $\mathrm{O}_{3}$. Acid rain is the result of excessive $\mathrm{NO}_{2}$ in the atmosphere. Adverse effects of $\mathrm{NO}_{2}$ on human health, especially the lung, have been presented by several researchers (Ackermann-Liebrich et al. 1997; Panella et al. 2000; Smith et al. 2000). Direct relationship between mortality rate and $\mathrm{NO}_{2}$ emission were illustrated also in different works (Burnett et al. 2004; Stieb et al. 2002). Tropospheric ozone is also responsible for a number of lung diseases. Asthma and lung inflammation are the two major outcomes of $\mathrm{O}_{3}$ in the atmosphere (Brunekreef and Holgate 2002; Holz et al. 1999; McDonnell et al. 1999; Schelegle et al. 2001). PM is the most harmful for human lung and is measured as the concentration of $\mathrm{PM}_{2.5}$ and $\mathrm{PM}_{10}$. Particles having diameter $2.5 \mu \mathrm{m}$ or lower fall under $\mathrm{PM}_{2.5}$ and particles having the diameter near $10 \mu \mathrm{m}$ fall under $\mathrm{PM}_{10}$ (Pandey et al. 2005). Recent work has shown the effects of $\mathrm{PM}_{2.5}$ on adverse cardiovascular (Rahman et al. 2021a) and respiratory outcomes (Rahman et al. 2021b) in Dhaka. Incomplete combustion is also responsible for the emission of $\mathrm{CO}$ in the atmosphere. It is extremely harmful for the health as it replaces oxygen in the hemoglobin. Apart from the lung diseases, $\mathrm{CO}$ also affects the human heart considerably (Blumenthal 2001). $\mathrm{SO}_{2}$ is responsible for asthma, bronchitis, and other lung diseases (Pandey et al. 2005). The main reason for $\mathrm{SO}_{2}$ emission in the atmosphere is the burning of high sulfur content fuels. Black carbon has high light absorbing capabilities that makes it one of the major climate active components of atmospheric aerosols (GIOVANNI 2021). It also takes part in radiative transfer that causes severe human health problem (GIOVANNI 2021).

All countries are facing severe economic crises due to the pandemic. Environmental degradation is closely related to the economic conditions (Jiang et al. 2020). Although there is uncertainty on how the economic conditions regulate environmental conditions, it is concluded that economic declines initially result in the significant environmental improvement (Akbostanc1 et al. 2009; Dutheil et al. 2020; Grossman and Krueger 1991; Ozcan et al. 2020; Panayotou 1993; Xu et al. 2016). However, severe environmental pollution emission reductions were expected worldwide such as in the 2007-09 economic decline (Mostafa et al. 2021). Air pollutant concentrations during COVID-19 lockdown have been assessed in many studies worldwide and comparison with the pre-COVID-19 state has been presented (Collivignarelli et al. 2020; Dantas et al. 2020; Gautam 2020; Mostafa et al. 2021; Muhammad et al. 2020; Nakada and Urban 2020; Sharma et al. 2020; Sicard et al. 2020; Torkmahalleh et al. 2021). This comparison of air quality between lockdown and pre-lockdown stages have been done in Bangladesh, as well (Islam et al. 2021b, c; Masum et al. 2020; Pavel et al. 2020). Islam et al. (2021b) assessed different air quality variables, such as $\mathrm{CO}_{2}, \mathrm{NO}_{2}, \mathrm{SO}_{2}$, etc. in Dhaka, Bangladesh only during the lockdown period. They also established relationship between meteorological variables with the air pollutants. Multiple linear regression was also performed to establish relationship between COVID-19 cases and air pollution concentrations. No comparison among air qualities during prelockdown, lockdown, and post-lockdown was provided. Islam et al. (2021c) compared the air quality during lockdown period with the pre-lockdown period in Bangladesh. However, the post-lockdown period was not taken into consideration. In the Islam et al.'s $(2021 \mathrm{~b}, \mathrm{c})$ work, they relied on only satellite data for the comparison of air quality. Regression model was employed to establish a relationship between COVID-19 cases and air pollution. Pavel et al. in 2020 compared the air quality of Bangladesh during lockdown period with the period before lockdown (Pavel et al. 2020). They established a relationship between the climate variables and COVID-19 mortality and morbidity rate to identify the favorable condition for spreading of the virus. Hridoy et al. (2021) established a relationship between meteorological variables, such as mean temperature, precipitation, wind speed, and relative humidity with the daily COVID-19 cases. Air quality assessments during the pandemic have been done primarily in Dhaka, the capital of Bangladesh. Chattogram and Khulna cities were also assessed.

Therefore, previous works in Bangladesh did not provide any comparisons of air quality with the post-lockdown period. Statistical analyses including nonparametric tests like Kruskal-Wallis test and pairwise Dunn's 'Q' test along with the comparison of air qualities and meteorological properties among pre-lockdown, lockdown, and post-lockdown period, employed in this research, can be very effective to assess the air quality and meteorological conditions in Bangladesh during the three observation periods. This paper presents a systematic comparison between air quality and meteorological variables during pre-lockdown, lockdown, and post-lockdown periods in Rajshahi, Bangladesh by employing different statistical approaches. Also, the relationships between COVID-19 case rates and air pollutants and meteorological variables were estimated. 


\section{Research Methodology}

\subsection{Comparison of Air Quality and Meteorological Variables Between Pre-lockdown, Lockdown, and Post-lockdown Periods}

For the comparison of air quality, a number of air pollutants and air quality parameters have been taken into consideration. This work relies on two different data sources, i.e., satellite data and ground-based data from the archive of Ministry of Environment and Forests (MEF), Bangladesh. Satellite data have been found very reliable in recent years due to its reliability and their area of observation is not limited to specific regions (Engel-Cox et al. 2004). Therefore, $\mathrm{NO}_{2}$ and other gases in atmosphere can be reliably monitored using satellite data (Veefkind et al. 2007). From the timeaveraged maps generated from satellite data, comparison between air qualities between different timeline of a single region or comparison between two different places can easily be done. There is only one drawback in satellite monitoring, which is the occasional absence of data due to non-covering band in tropics (Engel-Cox et al. 2004; Veefkind et al. 2007). Time-averaged maps of different pollutants in troposphere have been generated from NASA's GIOVANNI platform (GIOVANNI 2021). From $24^{\circ} 07^{\prime}$ to $24^{\circ} 43^{\prime}$ north latitude and from $88^{\circ} 17^{\prime}$ to $88^{\circ} 58^{\prime}$ east longitude has been considered for inspecting the time-averaged maps, which is the geographical location of Rajshahi city (Banglapedia 2021). For satellite data analysis, lockdown period has been considered from April 2020 to June 2020. Pre-lockdown period and post-lockdown periods have been considered from April 2019 to June 2019 and April 2021 to June 2021, respectively. From the satellite data, time-averaged maps of $\mathrm{NO}_{2}, \mathrm{SO}_{2}$, $\mathrm{O}_{3}, \mathrm{CO}, \mathrm{PM}_{2.5}$, AOD, and black carbon emission in Rajshahi city have been generated. Table 1 represents the summary of the satellite data used in this study.

The major advantage of ground-based continuous air monitoring stations (CAMS) is that they provide numerical specific value at different times for a specific location. Therefore, CAMS data along with satellite data analysis can be a strong air quality monitoring tool. The Ministry of Environment, Forests and Climate Change (MEFC), Bangladesh regularly monitors different air pollutants in the atmosphere through a number of ground-based CAMS, which are located in different regions of the country (Ministry of Environment 2020). There are 16 CAMS situated at different cities of Bangladesh. CAMS-10 situated at $24.38 \mathrm{~N}$ latitude and 88.61E longitude monitors air quality in Rajshahi. At this site, $\mathrm{O}_{3}, \mathrm{PM}_{2.5}, \mathrm{PM}_{10}, \mathrm{SO}_{2}, \mathrm{NO}_{2}$, and $\mathrm{CO}$ are routinely measured (Ministry of Environment 2020). The ambient air quality standards of Bangladesh set by MEFC are presented in Table 2. For ground-based data analysis also, prelockdown, lockdown, and post-lockdown periods have been considered April 2019-June 2019, April 2020-June 2020, and April 2021-June 2021, respectively.

Different meteorological variables, such as average daily temperature, average daily dew point temperature, daily precipitation, and daily average wind speed, were calculated for April to June of 2019, 2020, and 2021 from National Centers for Environmental Information (NCEI) under National

Table 2 Standards of air quality of Bangladesh (MEFC 2020)

\begin{tabular}{lll}
\hline Pollutant & Objective & Average \\
\hline Sulfur dioxide & $80 \mu \mathrm{g} / \mathrm{m}^{3}(0.03 \mathrm{ppm})$ & Annual \\
& $365 \mu \mathrm{g} / \mathrm{m}^{3}(0.14 \mathrm{ppm})$ & $24 \mathrm{~h} \mathrm{(a)}$ \\
Carbon monoxide & $10 \mathrm{mg} / \mathrm{m}^{3}(9 \mathrm{ppm})$ & $8 \mathrm{~h} \mathrm{(a)}$ \\
& $40 \mathrm{mg} / \mathrm{m}^{3}(35 \mathrm{ppm})$ & $1 \mathrm{~h} \mathrm{(a)}$ \\
Ozone & $235 \mu \mathrm{g} / \mathrm{m}^{3}(0.12 \mathrm{ppm})$ & $1 \mathrm{~h} \mathrm{(d)}$ \\
& $157 \mu \mathrm{g} / \mathrm{m}^{3}(0.08 \mathrm{ppm})$ & $8 \mathrm{~h}$ \\
Lead $(\mathrm{Pb})$ & $0.50 \mu \mathrm{g} / \mathrm{m}^{3}$ & Annual \\
$\mathrm{NO}_{2}$ & $100 \mu \mathrm{g} / \mathrm{m}^{3}(0.053 \mathrm{ppm})$ & Annual \\
$\mathrm{PM}_{2.5}$ & $15 \mu \mathrm{g} / \mathrm{m}^{3}$ & Annual \\
& $65 \mu \mathrm{g} / \mathrm{m}^{3}$ & $24 \mathrm{~h}$ \\
$\mathrm{PM}_{10}$ & $50 \mu \mathrm{g} / \mathrm{m}^{3}$ & Annual (b) \\
& $150 \mu \mathrm{g} / \mathrm{m}^{3}$ & $24 \mathrm{~h} \mathrm{(c)}$ \\
\hline
\end{tabular}

(a) Should not exceed more than once per year. (b) Arithmetic mean should not exceed $50 \mu \mathrm{g} / \mathrm{m}^{3}$, annually. (c) The number of days per calendar year with a $24 \mathrm{~h}$ average of $150 \mu \mathrm{g} / \mathrm{m}^{3}$ should be less than or equal to one. (d) Number of days per annum with $0.12 \mathrm{ppm}$ maximum hourly average should not exceed one

Table 1 Summary of the air pollutants monitored using the satellite database in this research (GIOVANNI 2021)

\begin{tabular}{lll}
\hline Time-averaged maps & Unit & Description \\
\hline $\mathrm{NO}_{2}$ tropospheric column & $1 / \mathrm{cm}^{2}$ & $30 \%$ cloud screened. Daily 0.25 degree, OMI OMNO2d v003 \\
$\mathrm{AOD}$ & $\mathrm{N} / \mathrm{A}$ & Monthly $0.5 \times 0.625$ degree, MERRA-2 model M2IMNXGAS v5.12.4 \\
$\mathrm{PM}_{2.5}$ column mass density & $\mathrm{kg} / \mathrm{m}^{2}$ & Monthly $0.5 \times 0.625$ degree, MERRA-2 model M2TMNXAER v5.12.4 \\
$\mathrm{O}_{3}$ total column & $\mathrm{DU}$ & Daytime/ascending, daily 1 degree, AIRS AIRS3STD v006 \\
$\mathrm{CO}_{\text {surface concentration }}$ & $\mathrm{ppbv}$ & Monthly $0.5 \times 0.625$ degree, MERRA-2 model M2TMNXCHM v5.12.4 \\
$\mathrm{SO}_{2}$ column mass density & $\mathrm{kg} / \mathrm{m}^{2}$ & Monthly $0.5 \times 0.625$ degree, MERRA-2 model M2TMNXAER v5.12.4 \\
Black carbon column mass density & $\mathrm{kg} / \mathrm{m}^{2}$ & Monthly $0.5 \times 0.625$ degree, MERRA-2 model M2TMNXAER v5.12.4 \\
\hline
\end{tabular}


Oceanic and Atmospheric Administration (NOAA) (NOAA 2021). Variation of these meteorological variables throughout the observed periods (lockdown period from April 2020 to June 2020, pre-lockdown period from April 2019 to June 2019, and post-lockdown period from April 2021 to June 2021) have also been observed in this research.

\subsection{Statistical Analysis of the Observed Data}

Summary statistics have been calculated for the obtained dataset. Mean, standard deviation, 25th percentile, 75th percentile, skewness, kurtosis, coefficient of variation (CV), minimum value, maximum value, range, and median of the data during the pre-lockdown, lockdown, and post-lockdown periods have been determined. The nonparametric Kruskal-Wallis ANOVA on ranks was applied to the air quality and meteorological variables to decide on accepting or rejecting the null hypothesis. Null hypothesis in this analysis states that the means can be considered the same. After performing the Kruskal-Wallis tests, the variables for which statistical differences were observed were further analyzed through Dunn's Q test. This test illustrated which pair of each variable is responsible for significant statistical difference between the periods. In this test, the null hypothesis was that the means of the selected pairs are same.

\subsection{Relationship Between Daily COVID-19 Case Rates and the Observed Variables}

Daily COVID-19 case rates have been obtained from the website of Directorate General of Health Services, Bangladesh (DGHS 2021). These daily case rates are the ratio of daily confirmed COVID-19 cases and daily conducted laboratory tests. Daily case rates in spite of daily confirmed cases have been taken for better accuracy in analysis. Only the lockdown (April 2020-June 2020) and post-lockdown (April 2021-June 2021) data of the observed variables were taken into consideration for establishing the relationship with the case rates, as no COVID-19 case was there in the pre-lockdown period. Linear regression models were established for each variable, and corresponding coefficients of determination $\left(R^{2}\right)$ and Pearson correlation coefficients $(r)$ were determined.

\section{Results and Discussion}

\subsection{Comparison of Air Qualities and Meteorological Variables}

\subsubsection{Variation in $\mathrm{NO}_{2}$ Emissions}

Major sources of NO are automotive and industrial emissions (Verma and Kamyotra 2021). Time-averaged maps of $\mathrm{NO}_{2}$ total column for pre-lockdown (April 2019-June 2019), lockdown (April 2020-June 2020), and post-lockdown periods (April 2021-April 2021) in Rajshahi, Bangladesh are illustrated in Fig. 2a (GIOVANNI 2021). It can be seen that minimum tropospheric $\mathrm{NO}_{2}$ has been recorded in Rajshahi during the lockdown period. During both prelockdown and post-lockdown periods, the tropospheric $\mathrm{NO}_{2}$ columns were higher than the lockdown period. Therefore, the improvement in air quality during the lockdown period was not sustainable as $\mathrm{NO}_{2}$ concentration in atmosphere increased during the post-lockdown period. Mostafa et al. predicted this drastic increase in air pollutant after the lockdown period (Mostafa et al. 2021). Similar increases in air pollution during post-lockdown state in China have been observed (Abnett 2020). In different cities of Bangladesh, considerable reductions of atmospheric $\mathrm{NO}_{2}$ have been observed in a number of studies (Islam et al. 2021b, c; Metya et al. 2020; Mishra and Kulshrestha 2021; Pavel et al. 2020). Similar situations have been reported worldwide, such as in India (Gautam 2020; Sharma et al. 2020; Verma and Kamyotra 2021), China (Wang and Su 2020), Brazil (Dantas et al. 2020), Egypt (Mostafa et al. 2021), Milan in Italy (Collivignarelli et al. 2020), etc. Similar situations have been observed in the CAMS data. Figure 3 a represents mean and standard deviation of $24 \mathrm{~h}$ average $\mathrm{NO}_{2}$ emission in Rajshahi during pre-lockdown (April 2019-June 2019), lockdown (April 2020-June 2020), and post-lockdown periods (April 2021-June 2021) (CASE 2021). It is clear that $\mathrm{NO}_{2}$ emissions across Rajshahi gradually decreased to a minimum in the lockdown stage and started to increase after the lockdown was lifted. A minimum of $9.37 \mathrm{ppb} \mathrm{NO}_{2}$ emission has been observed during the lockdown period and then started to increase in the post-lockdown period. Therefore, CAMS data correspond to the time-averaged maps generated from the available satellite data, which has been illustrated earlier.

\subsubsection{Variation in Tropospheric Ozone Concentration}

Ozone can be found in both stratosphere and troposphere. However, stratospheric ozone is beneficial for human being by preventing harmful UV rays from sun from reaching the earth surface, where tropospheric ozone is harmful to human health. Time-averaged maps of ozone total column in troposphere during lockdown, pre-lockdown, and postlockdown periods are illustrated in Fig. 2b (GIOVANNI 2021). As the color in the figure shifts from blue to red in the figure, the higher is the tropospheric ozone concentration. Considerable improvement of air quality in terms of ozone in Rajshahi city was observed during the lockdown period as seen in figure (275.8-277.8 DU). No significant variations in ozone concentrations were observed between 

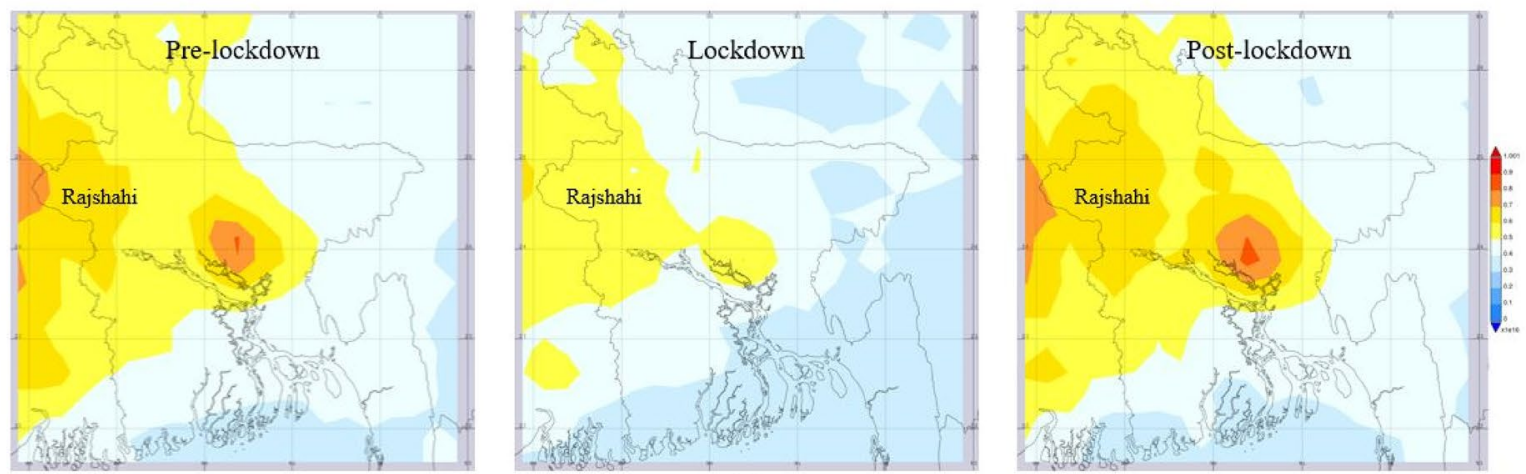

(a)
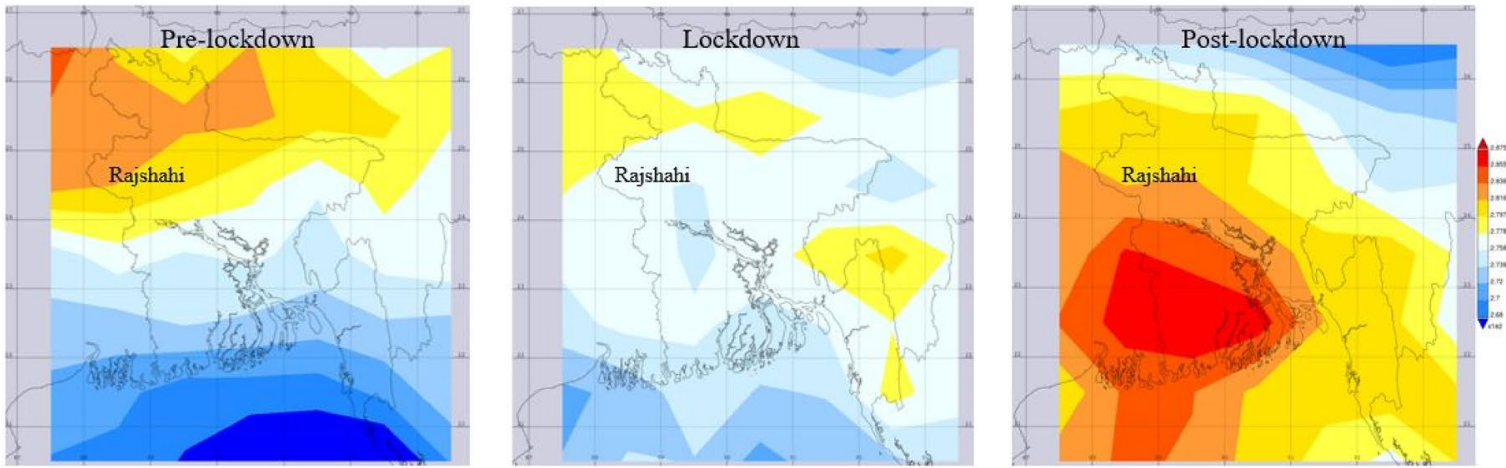

(b)
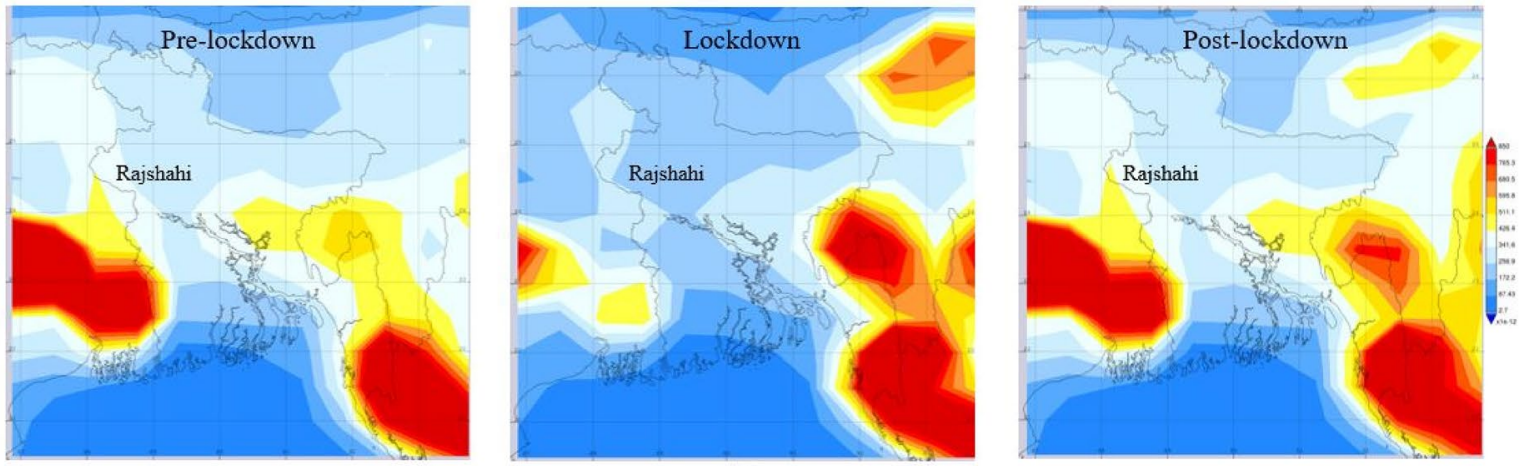

(c)
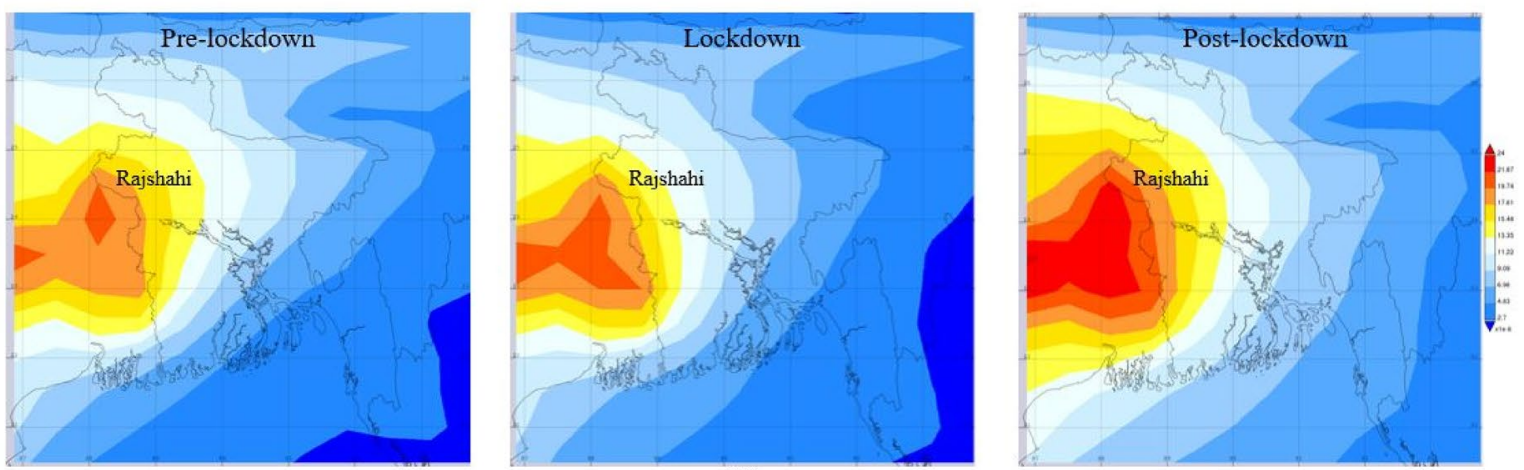

(d)

Fig. 2 Time-averaged maps of pollutants (a) $\mathrm{NO}_{2}$ total column $\left(\mathrm{cm}^{-2}\right), \mathbf{b ~ O} \mathrm{O}_{3}$ total column (DU), c CO mass concentration $\left(\mathrm{kg} \cdot \mathrm{m}^{-2} \cdot \mathrm{s}^{-1}\right)$, d $\mathrm{SO}_{2}$ column mass density $\left(\mathrm{kg} \mathrm{m}^{-2}\right)$, e $\mathrm{PM}_{2.5}$ column mass density $\left(\mathrm{kg} \mathrm{m}^{-3}\right)$, f AOD, and $\mathbf{g}$ black carbon column mass density $\left(\mathrm{kg} \mathrm{m}^{-2}\right)$ over Rajshahi, Bangladesh during pre-lockdown, lockdown, and postlockdown periods (GIOVANNI 2021) 

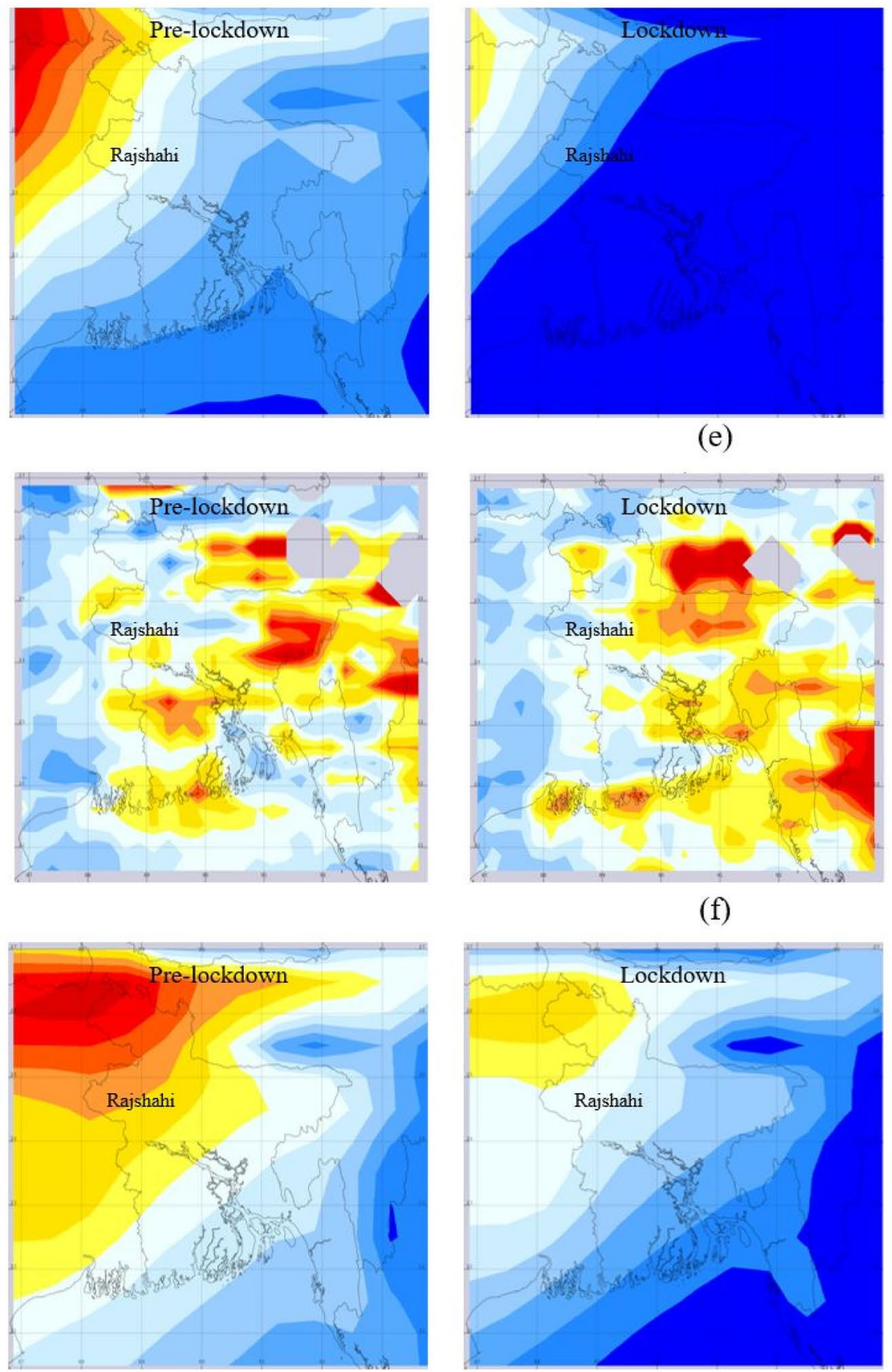

(g)

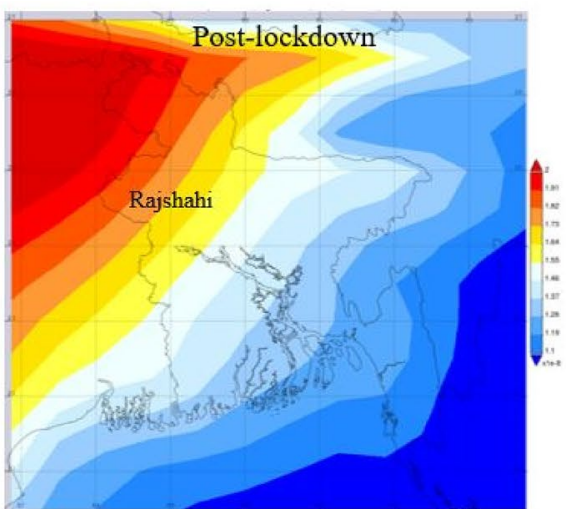

(e)
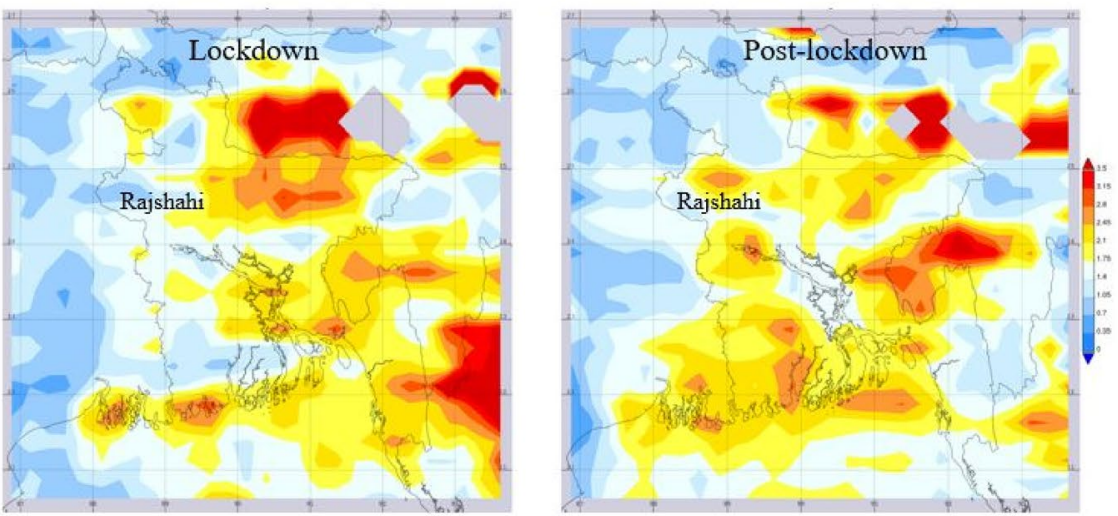

(f)

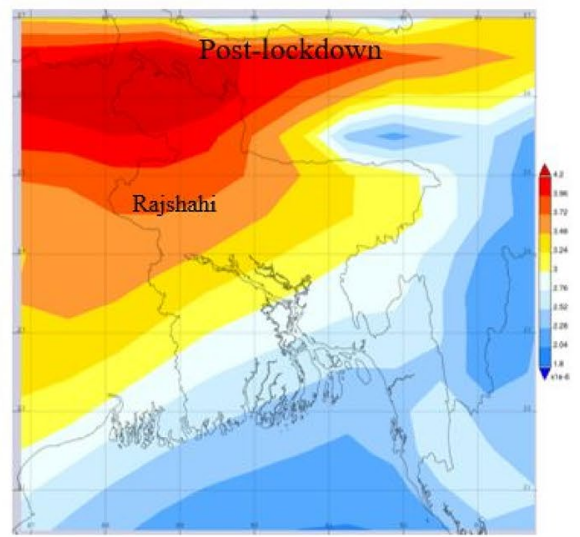

Fig. 2 (continued)

pre-lockdown and post-lockdown period. In each period, the values varied from 279.7 DU to 283.6 DU. Therefore, the improvement during lockdown was not sustained. Mean and standard deviation of $8 \mathrm{~h}$ average ozone concentration ( $\mathrm{ppb}$ ) over Rajshahi obtained from CAMS are illustrated in Fig. 3 b (CASE 2021). $\mathrm{O}_{3}$ concentrations were also minimal during lockdown period with a mean value of $5.58 \mathrm{ppb}$. This finding is in contract to most other locations that have been reported in the literature where they found that $\mathrm{O}_{3}$ increased during the lockdown period due to the reduced $\mathrm{NO}$ emissions and resulting titration (e.g., Santoso et al. 2021). During the post-lockdown period, $\mathrm{O}_{3}$ concentrations started to increase and produced a mean of $24.47 \mathrm{ppb}$ in post-lockdown stage. These results correspond with the satellite data and the same conclusion can be drawn. As formation of $\mathrm{O}_{3}$ is closely related to $\mathrm{NO}_{2}$, the scenarios for both $\mathrm{NO}_{2}$ and $\mathrm{O}_{3}$ have been observed 


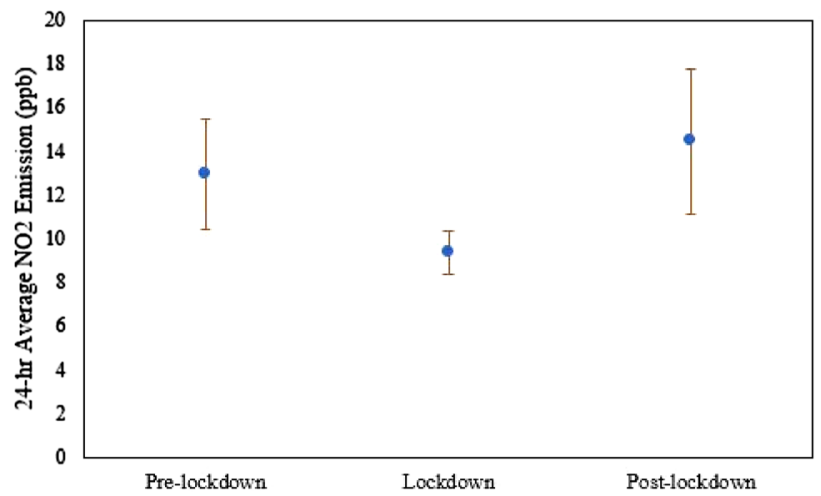

(a)

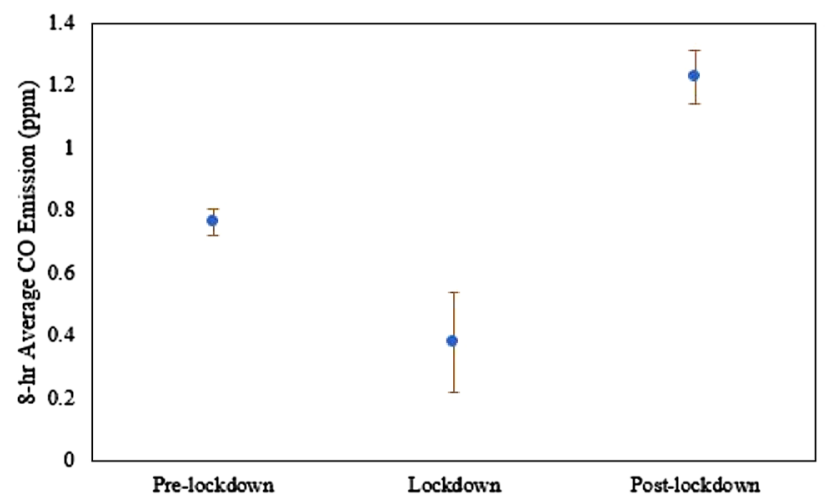

(c)

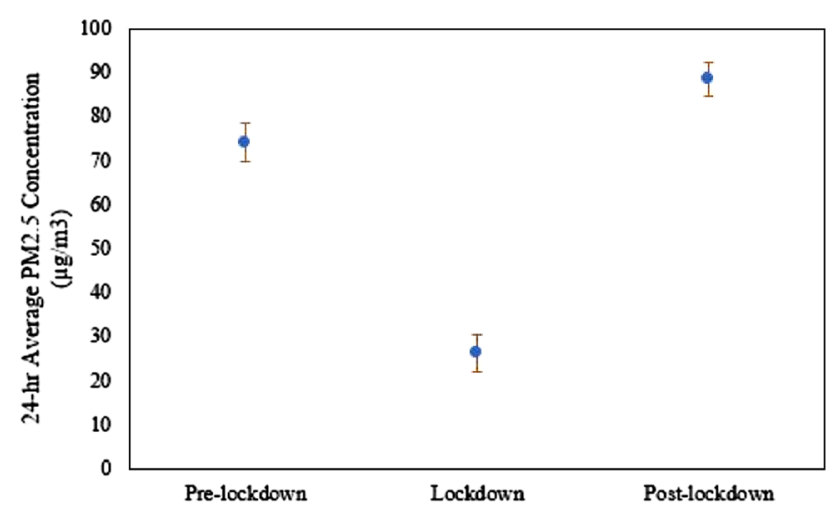

(e)

Fig. 3 Variation of each pollutant (a) $24 \mathrm{~h}$ average $\mathrm{NO}_{2}$ emission (ppb), b $8 \mathrm{~h}$ average ozone concentration (ppb), c $8 \mathrm{~h}$ average $\mathrm{CO}$ emissions (ppm), d $24 \mathrm{~h}$ average $\mathrm{SO}_{2}$ concentration (ppb), e $24 \mathrm{~h}$

in similar fashion, suggesting that Rajshahi is likely in a NOx-limited regime (Seinfeld and Pandis 2016).

\subsubsection{Variation in Carbon Monoxide Concentrations}

Vehicle exhaust is a major source of $\mathrm{CO}$ in atmosphere (Pérez-Martínez et al. 2014). It was expected that reduction

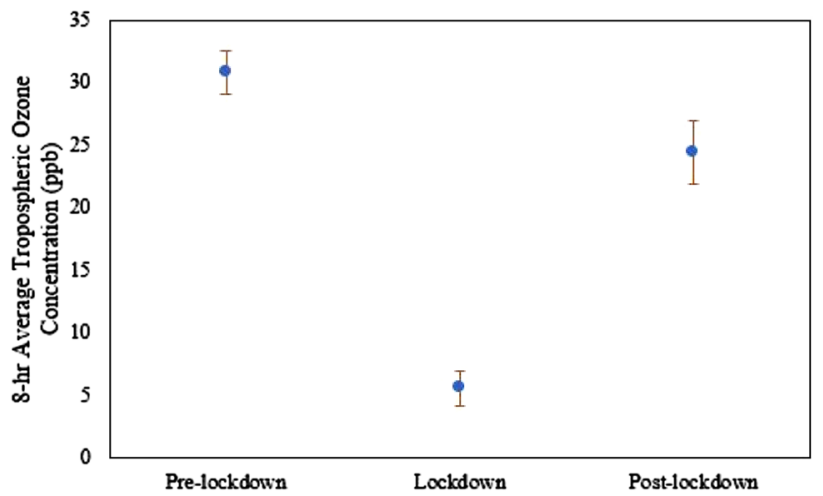

(b)

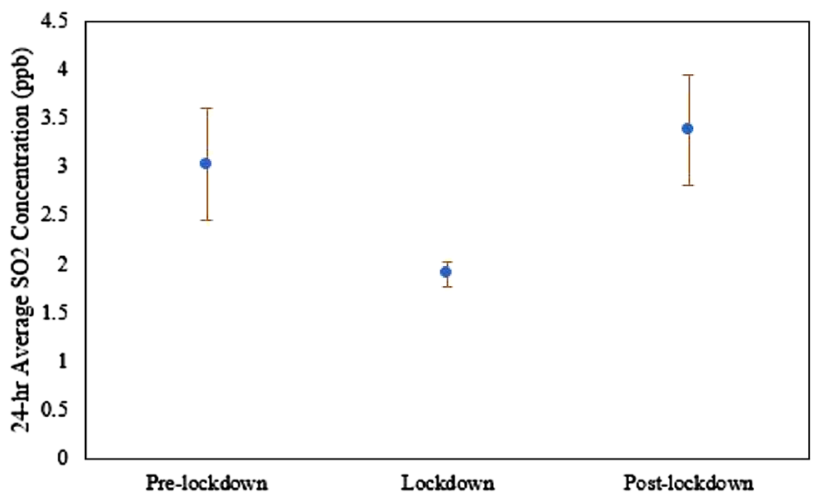

(d)

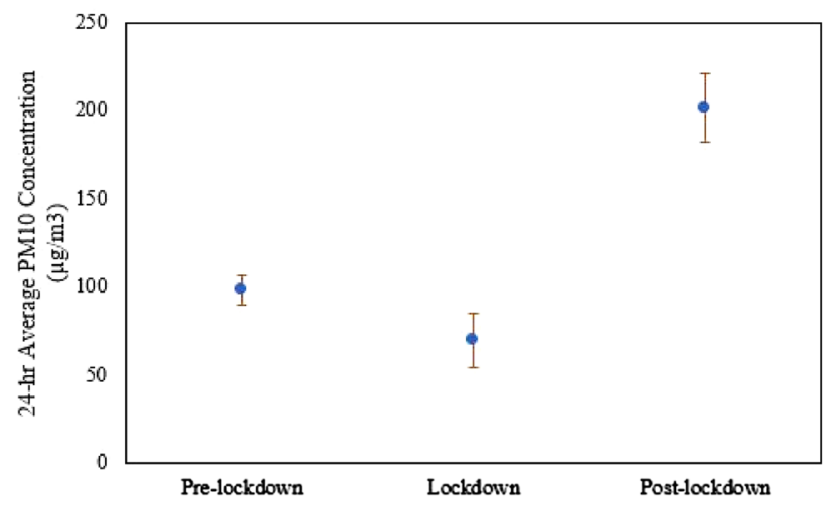

(f)

average $\mathrm{PM}_{2.5}$ concentration $\left(\mu \mathrm{g} / \mathrm{m}^{3}\right)$, and $\mathbf{f} 24 \mathrm{~h}$ average $\mathrm{PM}_{10}$ concentration $\left(\mu \mathrm{g} / \mathrm{m}^{3}\right)($ CASE 2021$)$

in $\mathrm{CO}$ emissions would occur, since vehicles were not in operation during the lockdown period. Time-averaged maps of CO mass concentration during pre-lockdown, lockdown, and post-lockdown periods in Rajshahi are presented in Fig. 2c (GIOVANNI 2021). The more the color of the figure shifts from blue to red, the higher the $\mathrm{CO}$ concentration is in the atmosphere. It is clear from the figure that $\mathrm{CO}$ 
concentrations were minimum during the lockdown period and maximum in post-lockdown period. Thus, similar to the previous results, the improvement in air quality in terms of $\mathrm{CO}$ was not sustained.

The CAMS 8-h average CO concentrations (mean and standard deviation) in Rajshahi during the lockdown, prelockdown, and post-lockdown periods are illustrated in Fig. 3c (CASE 2021). CO concentrations were reduced during the lockdown and reached a minimum value of $0.38 \mathrm{ppb}$ during the lockdown stage. However, emissions started to increase in the post-lockdown period similar to the satellite data. Considerable reductions of $\mathrm{CO}$ were observed in different cities of Bangladesh and in other countries of the world (Collivignarelli et al. 2020; Dantas et al. 2020; Nakada and Urban 2020; Sharma et al. 2020; Wang and Su 2020).

\subsubsection{Variation in Sulfur Dioxide Concentrations}

Figure $2 \mathrm{~d}$ shows time-averaged maps of $\mathrm{SO}_{2}$ mass column density over Rajshahi during the pre-lockdown, lockdown, and post-lockdown periods (GIOVANNI 2021). As the color shifts from blue to red in the figure, atmospheric concentrations of $\mathrm{SO}_{2}$ increase. Slight reductions of $\mathrm{SO}_{2}$ concentration in atmosphere during lockdown were observed. Although the differences among the three stages were not significant, the reduction in $\mathrm{SO}_{2}$ concentration during lockdown was observable, and increased pollution during post-lockdown period was also seen. Therefore, the improvement in air quality was not permanent.

CAMS $\mathrm{SO}_{2}$ data during the observed period were not consistently available. Like other parameters, a minimum $\mathrm{SO}_{2}$ concentration of $1.9 \mathrm{ppb}$ was observed in the lockdown period, and then, the concentration increased in post-lockdown period, as shown in Fig. 3d. Reduction of $\mathrm{SO}_{2}$ during lockdown has been observed in several researches worldwide (Collivignarelli et al. 2020; Mahato et al. 2020; Wang et al. 2019).

\subsubsection{Variation in Particulate Matter Concentrations}

The largest source in Rajshahi is brick kilns (40.2\%) with a substantial contribution from biomass burning (Begum et al. 2014) including transboundary pollution from across the IGP (Ommi et al. 2017). Lockdown resulted in the reduction of automobile operation, local brick making, and some other industries producing an expected reduction in PM. Timeaveraged maps of $\mathrm{PM}_{2.5}$ column mass density over Rajshahi during pre-lockdown, lockdown, and post-lockdown periods are illustrated in Fig. 2e (GIOVANNI 2021). The more the color in the figure shifts from blue to red, the high the concentration of $\mathrm{PM}_{2.5}$ is in the atmosphere. Lockdown is clearly responsible for substantial reductions in $\mathrm{PM}_{2.5}$ in the atmosphere. Similar to the cases for the other pollutants, dark reddish spots were visible in the post-lockdown period indicating the maximum concentration of $\mathrm{PM}_{2.5}$ in the postlockdown period. Therefore, the improvement in air quality during lockdown was not sustained and the concentration in post-lockdown period became even higher than the prelockdown period.

CAMS data for both $\mathrm{PM}_{2.5}$ and $\mathrm{PM}_{10}$ were available in Rajshahi. Figure $3 \mathrm{~d}$ and Fig. 3e present the mean and standard deviation of $\mathrm{PM}_{2.5}$ and $\mathrm{PM}_{10}$ concentration, respectively, in Rajshahi city during the pre-lockdown, lockdown, and post-lockdown periods (CASE 2021). In case of both $\mathrm{PM}_{2.5}$ and $\mathrm{PM}_{10}$, reduction of the $\mathrm{PM}$ concentrations was observed during the lockdown stage, but they increased in the postlockdown stage. In the post-lockdown stage, the maximum PM concentration was observed, and higher than the prelockdown stage just like the satellite data. The average $\mathrm{PM}_{2.5}$ concentration was $26.33 \mu \mathrm{g} / \mathrm{m}^{3}$ in lockdown, while the average $\mathrm{PM}_{10}$ concentration was $69.60 \mu \mathrm{g} / \mathrm{m}^{3}$ during the lockdown period. The highest average $\mathrm{PM}_{2.5}$ of $88.67 \mu \mathrm{g} / \mathrm{m}^{3}$ and $201.70 \mu \mathrm{g} / \mathrm{m}^{3}$ for the average $\mathrm{PM}_{10}$ were measured during the post-lockdown period. Therefore, both the satellite and CAMS data showed that the air quality improvement during the lockdown period was not sustained. Similar results have been observed in different cities throughout the world (Bao and Zhang 2020; Collivignarelli et al. 2020; Dantas et al. 2020; Mahato et al. 2020; Qin et al. 2004; Sharma et al. 2020; Tobías et al. 2020).

\subsubsection{Variation in Aerosol Optical Depth (AOD)}

The more particles that are present in the atmosphere, the greater will be the blockage of solar radiation. AOD measures this amount of solar radiation intensity being blocked by the particles (ESRL 2021). Therefore, higher AOD reflects higher PM concentrations and will be injurious to human health, visibility, and the ecosystem. Time-averaged maps of AOD over Rajshahi during the pre-lockdown, lockdown, and post-lockdown stages are presented in Fig. 2f (GIOVANN 2021). The more the color in the figure shifts from blue to red, the higher the AOD is. The minimum AOD was observed during the lockdown stage (0.70-1.75). Comparatively high values of AOD were observed in post-lockdown stage, and they were higher than in the pre-lockdown period (1.40-2.80). Thus, in this case, the improvement was also not permanent. Reductions in the atmospheric aerosol has also been observed in different studies around the world (Bao and Zhang 2020; Collivignarelli et al. 2020; Dantas et al. 2020; Sharma et al. 2020). Due to the unavailability of CAMS data, this work only relies on satellite data for AOD monitoring. 


\subsubsection{Variation in Black Carbon Concentrations}

Time-averaged maps of the black carbon column mass density over Rajshahi during the lockdown, pre-lockdown, and post-lockdown are presented in Fig. 2g. Minimum black carbon concentrations were observed in the lockdown period. However, severe dark reddish spots were clearly visible in post-lockdown period indicating rapid rise of the black carbon concentrations in this period. Thus, the improvement in lockdown was not sustained as was the situation with the other air pollutants in Rajshahi.

\subsubsection{Changes in Meteorological Variables}

Variations of average temperature, average dew-point temperature, wind speed, and precipitation during the pre-lockdown, lockdown, and post-lockdown periods are shown in Fig. 4 (NOAA 2021). Considerable variation of these meteorological parameters was observed throughout the study. Average temperature was lowest in the lockdown period $\left(83.08^{\circ} \mathrm{F}\right)$ and maximum in post-lockdown period $\left(85.84^{\circ} \mathrm{F}\right)$ (Fig. 4a). Average dew-point temperature was also minimum in the lockdown period $\left(75.01^{\circ} \mathrm{F}\right)$. Variations of average

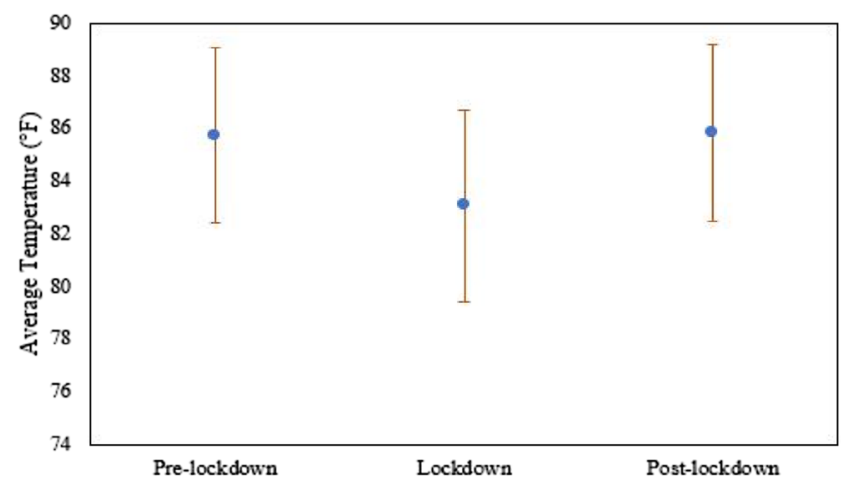

(a)

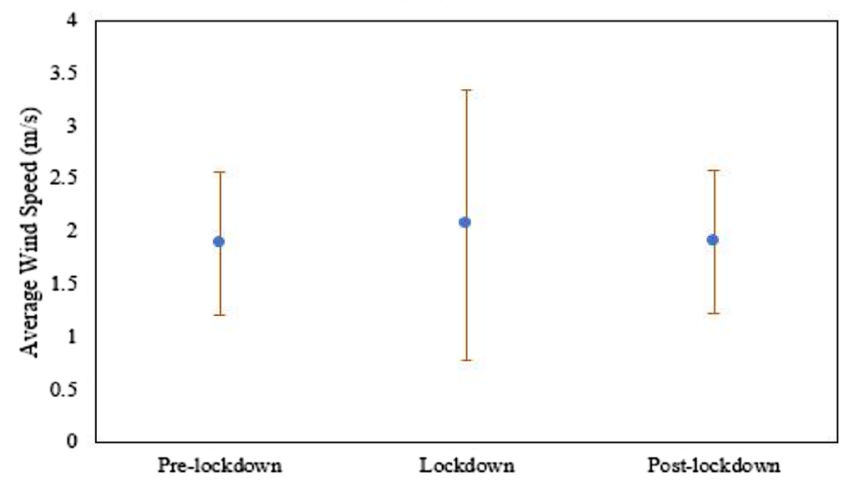

(c) dew-point temperature are shown in Fig. 4b. Minimum wind speed was observed in the pre-lockdown period $(1.895 \mathrm{~m} / \mathrm{s})$; while maximum wind speed was observed in the lockdown period $(2.07 \mathrm{~m} / \mathrm{s})($ Fig. $4 \mathrm{c})$. Finally, the minimum precipitation was observed in the lockdown stage (average $0.216 \mathrm{~cm}$ ) and maximum in post-lockdown stage $(0.369 \mathrm{~cm}$ on average $)$ (Fig. 4d).

\subsection{Statistical Analyses}

Statistical analyses were performed to assess the characteristics of the obtained data during the pre-lockdown, lockdown, and post-lockdown periods. Mean, standard deviation, 25th percentile, 75th percentile, skewness, kurtosis, coefficient of variation (CV), minimum value, maximum value, range, and median were calculated for the air pollutants and meteorological variables during the pre-lockdown, lockdown, and post-lockdown stages. A summary of the statistical data analysis for the air quality parameters and meteorological variables are presented in Tables 3 and 4, respectively. To determine if the variations of the observed data among the observed periods were statistically different from one another, Kruskal-Wallis ANOVA on rank analyses have been done for each air pollutant and meteorological

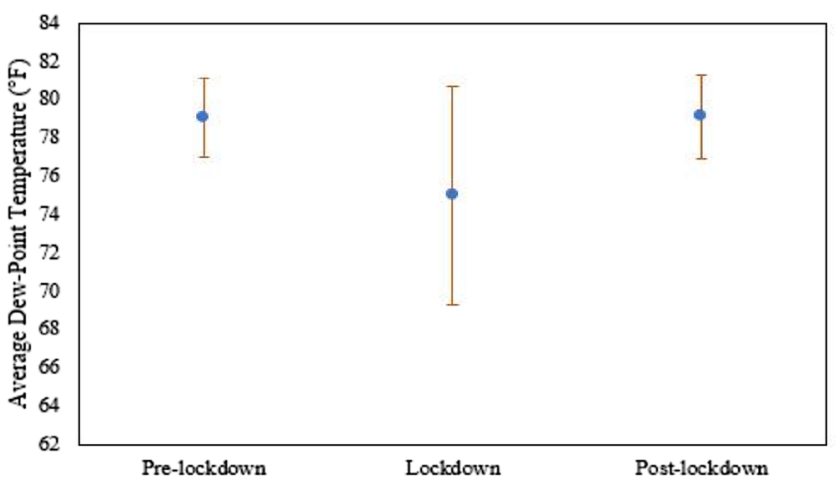

(b)

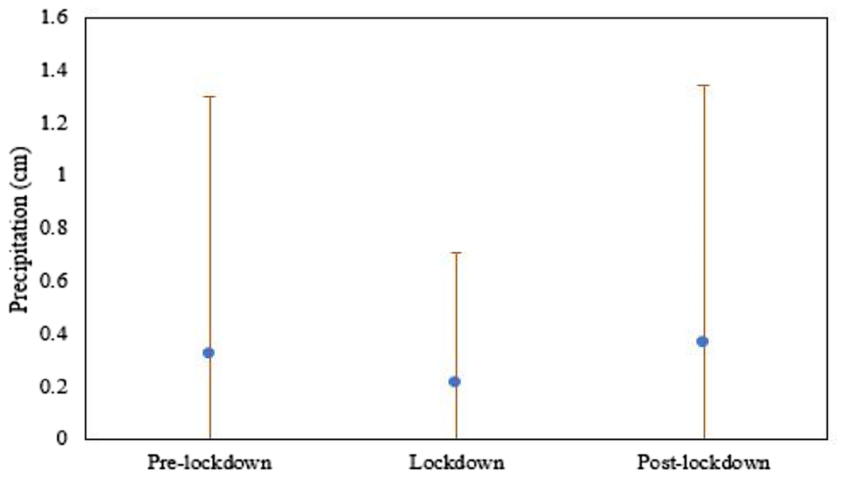

(d)

Fig. 4 Variation of (a) average temperature $\left({ }^{\circ} \mathrm{F}\right)$, b dew-point temperature $\left({ }^{\circ} \mathrm{F}\right)$, c average wind speed $(\mathrm{m} / \mathrm{s})$, and $\mathbf{d}$ precipitation $(\mathrm{cm})$ during prelockdown, lockdown, and post-lockdown period (NOAA 2021) 
Table 3 Summary of the statistical data of the air pollutants during the observed periods

\begin{tabular}{|c|c|c|c|c|c|c|c|}
\hline Observed period & Statistical parameters & $\begin{array}{l}\mathrm{NO}_{2} \\
(\mathrm{ppb})\end{array}$ & $\begin{array}{l}\mathrm{O}_{3} \\
(\mathrm{ppb})\end{array}$ & $\begin{array}{l}\mathrm{CO} \\
(\mathrm{ppm})\end{array}$ & $\begin{array}{l}\mathrm{SO}_{2} \\
(\mathrm{ppb})\end{array}$ & $\begin{array}{l}\mathrm{PM}_{2.5} \\
\left(\mu \mathrm{g} / \mathrm{m}^{3}\right)\end{array}$ & $\begin{array}{l}\mathrm{PM}_{10} \\
\left(\mu \mathrm{g} / \mathrm{m}^{3}\right)\end{array}$ \\
\hline \multirow[t]{11}{*}{ Pre-lockdown period (April 2019-June 2019) } & Mean & 12.97 & 30.80 & 0.76 & 3.03 & 74.07 & 98.67 \\
\hline & Standard deviation & 2.51 & 1.73 & 0.04 & 0.57 & 4.38 & 8.5 \\
\hline & 25th percentile & 11.9 & 29.9 & 0.74 & 2.8 & 72.1 & 95.5 \\
\hline & 75th percentile & 14.4 & 31.6 & 0.78 & 3.4 & 76.4 & 103.5 \\
\hline & Skewness & -1.06 & 0.98 & 1.29 & -1.28 & -0.64 & -1.49 \\
\hline & Kurtosis & N/A & N/A & N/A & N/A & N/A & N/A \\
\hline & Coefficient of variation, CV (\%) & 19.36 & 5.63 & 5.45 & 18.9 & 5.92 & 8.62 \\
\hline & Min value & 10.2 & 29.3 & 0.73 & 2.4 & 69.4 & 89.0 \\
\hline & Max value & 15.1 & 32.7 & 0.81 & 3.5 & 78.1 & 105.0 \\
\hline & Range & 4.9 & 3.4 & 0.08 & 1.1 & 8.7 & 16.0 \\
\hline & Median & 13.6 & 30.4 & 0.75 & 3.2 & 74.7 & 102.0 \\
\hline \multirow[t]{11}{*}{ Lockdown period (April 2020-June 2020) } & Mean & 9.37 & 5.58 & 0.38 & 1.90 & 26.33 & 69.60 \\
\hline & Standard deviation & 0.99 & 1.4 & 0.16 & 0.13 & 4.05 & 15.3 \\
\hline & 25 th percentile & 9.1 & 4.8 & 0.32 & 1.8 & 24.1 & 60.8 \\
\hline & 75th percentile & 9.9 & 6.2 & 0.47 & 2.00 & 28.1 & 74.7 \\
\hline & Skewness & -1.68 & 0.68 & -1.26 & -0.67 & 1.07 & 1.68 \\
\hline & Kurtosis & N/A & N/A & N/A & $? ? ?$ & N/A & N/A \\
\hline & Coefficient of variation, CV (\%) & 10.5 & 25.50 & 42.35 & 6.90 & 15.38 & 21.98 \\
\hline & Min value & 8.2 & 4.3 & 0.20 & 1.76 & 22.9 & 59.5 \\
\hline & Max value & 10.0 & 7.1 & 0.51 & 2.02 & 30.8 & 87.2 \\
\hline & Range & 1.8 & 2.8 & 0.31 & 0.26 & 7.9 & 27.7 \\
\hline & Median & 9.9 & 5.4 & 0.43 & 1.92 & 25.3 & 62.1 \\
\hline \multirow[t]{11}{*}{ Post-lockdown period (April 20,201-June 2021) } & Mean & 14.47 & 24.47 & 1.23 & 3.39 & 88.67 & 201.70 \\
\hline & Standard deviation & 3.30 & 2.58 & 0.09 & 0.57 & 3.75 & 19.59 \\
\hline & 25th percentile & 12.8 & 23.2 & 1.18 & 3.1 & 87.3 & 192.3 \\
\hline & 75th percentile & 16.1 & 25.9 & 1.27 & 3.7 & 90.8 & 211.8 \\
\hline & Skewness & 0.09 & -0.74 & 0.84 & 0.29 & -1.54 & -0.35 \\
\hline & Kurtosis & N/A & N/A & N/A & N/A & N/A & N/A \\
\hline & Coefficient of variation, $\mathrm{CV}(\%)$ & 22.81 & 10.53 & 7.03 & 16.71 & 4.23 & 9.71 \\
\hline & Min value & 11.2 & 21.7 & 1.15 & 2.8 & 84.4 & 181.4 \\
\hline & Max value & 17.8 & 26.8 & 1.32 & 4.00 & 91.4 & 220.5 \\
\hline & Range & 6.6 & 5.1 & 0.17 & 1.2 & 7.0 & 39.1 \\
\hline & Median & 14.4 & 24.9 & 1.21 & 3.4 & 90.2 & 203.2 \\
\hline
\end{tabular}

variable. The null hypothesis in this analysis states that the means of the data taken at different stages can be considered equal. Therefore, from these nonparametric tests, decision on accepting or rejecting null hypothesis were taken. The Kruskal-Wallis tests for air quality parameters and meteorological variables are summarized in Table 5. After performing the Kruskal-Wallis tests, the variables which showed significant statistical difference among the observed periods were analyzed for pairwise differences using Dunn's method (Dunn 1964). In this work, $\mathrm{O}_{3}, \mathrm{CO}, \mathrm{PM}_{2.5}, \mathrm{PM}_{10}$, average temperature, and average dew-point temperature showed significant statistical difference between the observed periods in the Kruskal-Wallis tests. The null hypothesis in the Dunn test was that the rank sums of the selected pair are the same.
The Dunn's test results are presented in Table 6. From these analyses, the pre-lockdown and lockdown pair for ozone and lockdown and post-lockdown pairs for $\mathrm{CO}, \mathrm{PM}_{2.5}, \mathrm{PM}_{10}$, average temperature, and average dew-point temperature are the main pairs showing statistically significant differences.

\subsection{Relationship Between COVID-19 Case Rates and Air Pollution Parameters, as well as Meteorological Variables}

Since COVID-19 directly affects the human lung, it was expected that high air pollution would be associated with higher daily COVID-19 case rates (Islam et al. 2021b). Instead of using the daily confirmed case numbers, the ratio 
Table 4 Summary of the statistical data of the meteorological properties during the observed periods

\begin{tabular}{|c|c|c|c|c|c|}
\hline Observed period & Statistical parameters & $\begin{array}{l}\text { Average } \\
\text { temperature } \\
\left({ }^{\circ} \mathrm{F}\right)\end{array}$ & $\begin{array}{l}\text { Dew-point } \\
\text { temperature } \\
\left({ }^{\circ} \mathrm{F}\right)\end{array}$ & $\begin{array}{l}\text { Average } \\
\text { wind speed } \\
(\mathrm{m} / \mathrm{s})\end{array}$ & Precipitation $(\mathrm{cm})$ \\
\hline \multirow[t]{11}{*}{ Pre-lockdown period (April 2019-June 2019) } & Mean & 85.73 & 79.07 & 1.89 & 0.32 \\
\hline & Standard deviation & 3.34 & 2.09 & 0.68 & 0.98 \\
\hline & 25th percentile & 83.8 & 77.9 & 1.40 & 0 \\
\hline & 75th percentile & 88.1 & 80.4 & 2.30 & 0 \\
\hline & Skewness & -0.77 & -0.39 & -0.08 & 4.21 \\
\hline & Kurtosis & 0.26 & 0.03 & -0.37 & 19.54 \\
\hline & Coefficient of variation, CV (\%) & 3.90 & 2.64 & 35.8 & 302 \\
\hline & Min Value & 76.7 & 73.6 & 0.70 & 0 \\
\hline & Max Value & 90.4 & 82.8 & 3.40 & 5.28 \\
\hline & Range & 13.7 & 9.20 & 2.70 & 5.28 \\
\hline & Median & 86.4 & 79.0 & 1.90 & 0 \\
\hline \multirow[t]{11}{*}{ Lockdown period (April 2020-June 2020) } & Mean & 83.08 & 75.01 & 2.07 & 0.22 \\
\hline & Standard deviation & 3.64 & 5.69 & 1.28 & 0.49 \\
\hline & 25th percentile & 80.6 & 72.15 & 1.50 & 0 \\
\hline & 75th percentile & 86.0 & 79.45 & 2.28 & 0.20 \\
\hline & Skewness & -0.52 & -1.07 & 4.65 & 3.27 \\
\hline & Kurtosis & -0.59 & 0.74 & 31.37 & 12.29 \\
\hline & Coefficient of variation, CV (\%) & 4.38 & 7.58 & 61.91 & 228 \\
\hline & Min value & 74.5 & 59.2 & 0.70 & 0 \\
\hline & Max value & 89.2 & 82.0 & 11.40 & 2.9 \\
\hline & Range & 14.7 & 22.8 & 10.70 & 2.9 \\
\hline & Median & 84.1 & 76.3 & 1.80 & 0 \\
\hline \multirow{11}{*}{$\begin{array}{l}\text { Post-lockdown period (April 2021-June } \\
\text { 2021) }\end{array}$} & Mean & 85.84 & 79.10 & 1.90 & 0.37 \\
\hline & Standard deviation & 3.37 & 2.20 & 0.68 & 0.98 \\
\hline & 25 th percentile & 82.2 & 77.6 & 1.50 & 0 \\
\hline & 75th percentile & 88.5 & 80.7 & 2.50 & 0.26 \\
\hline & Skewness & -0.69 & -0.31 & -0.05 & 4.12 \\
\hline & Kurtosis & -0.26 & 0.09 & -0.57 & 19.36 \\
\hline & Coefficient of variation, CV (\%) & 3.93 & 2.78 & 35.81 & 264.74 \\
\hline & Min value & 77.8 & 73.4 & 0.60 & 0 \\
\hline & Max value & 90.4 & 83.2 & 3.30 & 5.35 \\
\hline & Range & 12.6 & 9.8 & 2.70 & 5.35 \\
\hline & Median & 86.3 & 79.1 & 1.80 & 0 \\
\hline
\end{tabular}

of daily confirmed cases to the number of daily laboratory tests were used to provide better accuracy in the regression model. The relationships between $\mathrm{NO}_{2}, \mathrm{O}_{3}, \mathrm{CO}, \mathrm{SO}_{2}, \mathrm{PM}_{2.5}$, and $\mathrm{PM}_{10}$ with the confirmed COVID-19 case rates in the form of linear regression are shown in Fig. 5. Very weak relationships were observed between case rates and the different air pollutants. Positive association of case rates with $\mathrm{PM}_{10}$ were observed in Fig. $5 \mathrm{f}\left(R^{2}=0.0016\right)$. Positive associations with case rates have also been reported in previous studies (Islam et al. 2021b; Martelletti and Martelletti 2020; Ogen 2020). However, negative relations were observed for $\mathrm{NO}_{2}\left(R^{2}=0.0842\right), \mathrm{O}_{3}\left(R^{2}=0.016\right), \mathrm{CO}\left(R^{2}=0.0566\right)$, $\mathrm{SO}_{2}\left(R^{2}=0.0285\right)$, and $\mathrm{PM}_{2.5}\left(R^{2}=0.0292\right)$. Although the government declared the nationwide lockdown from April 2020 to June 2020, different containment actions continued to be implemented up to December 2020. Thus, case rates became lower in the months of January 2021 and February 2021. However, in that period, air pollution was very high similar to when the lockdown was lifted. Additionally, a new variant of COVID-19 was observed in Bangladesh in March 2021 (IEDCR 2021). People began to no longer maintaining social distancing. Hence, COVID-19 case rates again started to increase as well as the mortality rate, although the pollution levels were consistent with the previous months. For these reasons, negative slopes were obtained for rest of the variables. Summary of the slopes, intercepts, coefficient 
Table 5 Kruskal-Wallis test results for different air pollutants and meteorological variables

\begin{tabular}{|c|c|c|c|c|c|c|c|c|}
\hline Pollutant & Period & Sample size & Sum of rank & Average rank & H-statistic Value & Chi-square & $p$ value & Decision on null \\
\hline \multirow[t]{3}{*}{$\mathrm{NO}_{2}$} & Pre-lockdown & 3 & 18 & 6 & 5.60 & 5.99 & 0.061 & Fail to reject \\
\hline & Lockdown & 3 & 6 & 2 & & & & \\
\hline & Post-lockdown & 3 & 21 & 7 & & & & \\
\hline \multirow[t]{3}{*}{$\mathrm{O}_{3}$} & Pre-lockdown & 3 & 24 & 8 & 7.20 & 5.99 & 0.027 & Reject null \\
\hline & Lockdown & 3 & 6 & 2 & & & & \\
\hline & Post-lockdown & 3 & 15 & 5 & & & & \\
\hline \multirow[t]{3}{*}{$\mathrm{CO}$} & Pre-lockdown & 3 & 15 & 5 & 7.20 & 5.99 & 0.027 & Reject null \\
\hline & Lockdown & 3 & 6 & 2 & & & & \\
\hline & Post-lockdown & 3 & 24 & 8 & & & & \\
\hline \multirow[t]{3}{*}{$\mathrm{SO}_{2}$} & Pre-lockdown & 3 & 18 & 6 & 5.60 & 5.99 & 0.061 & Fail to reject \\
\hline & Lockdown & 3 & 6 & 2 & & & & \\
\hline & Post-lockdown & 3 & 21 & 7 & & & & \\
\hline \multirow[t]{3}{*}{$\mathrm{PM}_{2.5}$} & Pre-lockdown & 3 & 15 & 5 & 7.2 & 5.99 & 0.027 & Reject null \\
\hline & Lockdown & 3 & 6 & 2 & & & & \\
\hline & Post-lockdown & 3 & 24 & 8 & & & & \\
\hline \multirow[t]{3}{*}{$\mathrm{PM}_{10}$} & Pre-lockdown & 3 & 15 & 5 & 7.20 & 5.99 & 0.027 & Reject null \\
\hline & Lockdown & 3 & 6 & 2 & & & & \\
\hline & Post-lockdown & 3 & 24 & 8 & & & & \\
\hline \multirow[t]{3}{*}{ Average temperature } & Pre-lockdown & 37 & 3719 & 100.51 & 21.54 & 5.99 & $2.10 \times 10^{-5}$ & Reject null \\
\hline & Lockdown & 90 & 6021.5 & 66.91 & & & & \\
\hline & Post-lockdown & 37 & 3789.5 & 102.42 & & & & \\
\hline \multirow{3}{*}{$\begin{array}{l}\text { Dew-point tempera- } \\
\text { ture }\end{array}$} & Pre-lockdown & 37 & 3767.5 & 101.82 & 23.01 & 5.99 & $1.01 \times 10^{-5}$ & Reject null \\
\hline & Lockdown & 90 & 5973.5 & 66.37 & & & & \\
\hline & Post-lockdown & 37 & 3789 & 102.41 & & & & \\
\hline \multirow[t]{3}{*}{ Average wind speed } & Pre-lockdown & 37 & 3107 & 83.97 & 0.05 & 5.99 & 0.975 & Fail to reject \\
\hline & Lockdown & 90 & 7369.5 & 81.88 & & & & \\
\hline & Post-lockdown & 37 & 3053.5 & 82.53 & & & & \\
\hline \multirow[t]{3}{*}{ Precipitation } & Pre-lockdown & 37 & 2761 & 74.62 & 1.56 & 5.99 & 0.459 & Fail to reject \\
\hline & Lockdown & 90 & 7751 & 86.12 & & & & \\
\hline & Post-lockdown & 37 & 3018 & 81.57 & & & & \\
\hline
\end{tabular}

of determination, and Pearson coefficient ' $r$ ' for different pollutants and the meteorological variables (average temperature, dew-point temperature, average wind speed, and precipitation) obtained during regression analysis are presented in Table 7.

The relationships between meteorological variables and COVID-19 case rates are shown in Fig. 6. All the meteorological variables showed weak positive correlations with COVID-19 case rates. Coefficient of determinations for temperature, wind speed, dew-point temperature, and precipitation have been observed 0.0646, 0.0098, 0.5323, and 0.0138 , respectively. Positive correlations for the different meteorological variables with COVID-19 transmission rates have been found in the previous studies throughout the world (Bashir et al. 2020; Islam et al. 2021a; Kafieh et al. 2020; Pedrosa 2020; Tosepu et al. 2020), although some exceptions were also observed (Liu et al. 2020; Zhu et al. 2020). Therefore, there exists a weak relationship between meteorological variables in Rajshahi and daily confirmed COVID-19 case rates.

\subsection{Influence of COVID-19 on Different Factors in Bangladesh}

The most important sector that has been greatly affected by the pandemic is the economy. All countries have experienced severe economic crises during the pandemic (Kumar et al. 2020; Mostafa et al. 2021). Reduction in the operation of industries, transportation of workers and goods, etc. are the prime reasons for the economic crisis worldwide (Fernandes 2020; McKibbin and Fernando 2020). Like other countries, Bangladesh has been facing several challenges due to the reduction of industrial activities during the lockdown. Since travel to and from China was stopped during the lockdown, some large projects requiring the aid of China (Padma rail link, Karnaphuli road tunnel, Padma bridge) were halted 
Table 6 Dunn's Q-test results for the variables that showed significant statistical difference

\begin{tabular}{lllll}
\hline Variables & Pair & Q value & Critical value \\
for $\propto=0.05$
\end{tabular}

(Begum et al. 2020). Vital economic lifelines in Bangladesh, such as agriculture, service sector, and industrial sector, were greatly affected by the lockdown. About BDT 570 million (7 million USD) loss incurred daily in the dairy industry alone as millions of liters of milk were left unsold during the lockdown (Begum et al. 2020). China annually imports about $70 \%$ of Bangladesh's crabs, and these shipments were stopped during the pandemic (Khaled 2020). The garment sector experienced losses of USD 2.6 billion during the lockdown period (Begum et al. 2020). Raw materials for pharmaceutical production are generally imported from India and China, which were hampered during the pandemic. Therefore, shortages of various medicines were observed during the lockdown. The price of hand sanitizers and face masks increased about $400 \%$ in the lockdown that caused great problems to the mass of people (Dhaka-Tribune 2020). A reduction of USD 3 billion in GDP (Gross Domestic Product) was predicted by Asian development bank (Begum et al. 2020). Tourism also contributes a significant portion of country's GDP (about 4.4\%) (World_Bank 2019). The government closed all the tourist spots in the country during the lockdown. As a result, in April 2020 alone, the tourism industry lost BDT 15 billion (180 million USD) and about 5000 people have lost their job in this sector (TOAB 2020).

Bangladesh declared an educational vacation on March 16, 2020 shutting all schools, colleges, and universities with an expectation to start 5 April, 2020 (MOE 2021). However, as the COVID scenario worsened, educational institutions were still closed as of 27 July 2021. Limited classes were conducted through online platforms to keep the students up to date. The government also allocated funds for poor people, so that they can also take part in online classes. A recent study by Begum et al. (2020) revealed that large numbers of students at the graduate level were suffering from excessive stress and anxiety issues as their graduation completion has been delayed. Huge social impacts have been observed in Bangladesh during the lockdown stage. Social panic and hatred were transmitted throughout the country through social media due to the transmission of different false or fake information. People stayed most of the time in their home enjoying leisure, which triggered greater use of social media. Therefore, rumors were rapidly transmitted creating havoc. A surge in crime and poverty were also noted in the lockdown period. Research showed that domestic violence against women increased drastically during the lockdown period and many women were suffering from anxiety disorder (Banna et al. 2020).

The lockdown period triggered the consumption of more food as observed by different studies (Mostafa et al. 2021; Nile 2020). The high food consumption is responsible for high waste generation and obesity. The authority took necessary steps by decreasing the waste collection interval time. However, both affected patients who did not test for the disease and normal people dumped the waste in the same site. This co-mixing of material was harmful for the waste collector and many workers were affected while handling these wastes. Again, generation of medical wastes increased drastically during the 


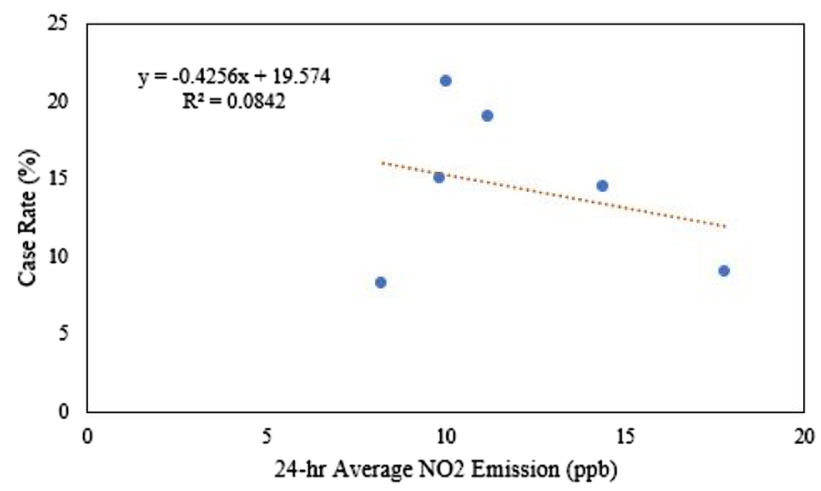

(a)

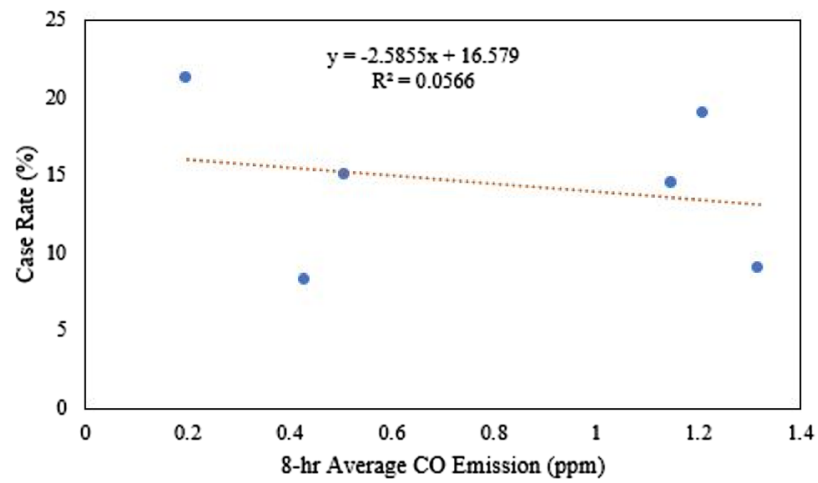

(c)

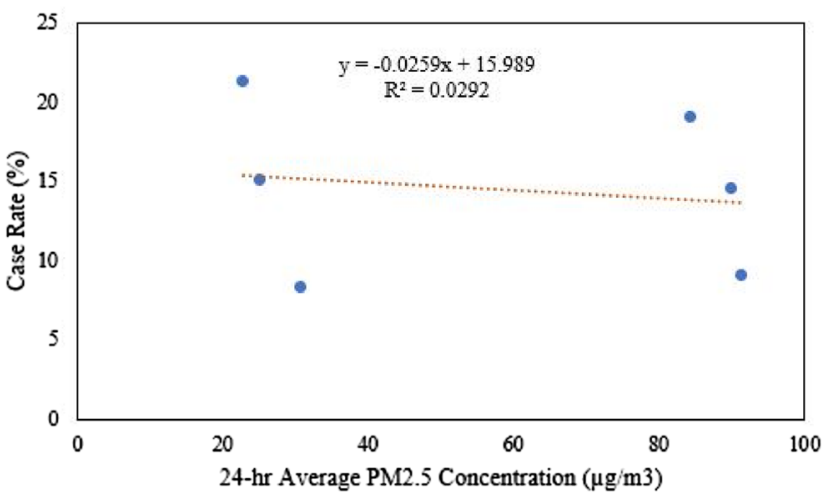

(e)

Fig. 5 Correlation between COVID-19 case rates and each pollutant: (a) $24 \mathrm{~h}$ average $\mathrm{NO}_{2}$ emission (ppb), b $8 \mathrm{~h}$ average ozone concentration (ppb), c $8 \mathrm{~h}$ average $\mathrm{CO}$ emissions (ppm), d $24 \mathrm{~h}$ average $\mathrm{SO}_{2}$

pandemic. Improper biomedical waste management is responsible for around 5.2 million deaths in Bangladesh every year (Rahman et al. 2020). In Dhaka alone, 206 tons of medical wastes are being generated daily (Rahman et al. 2020). These wastes are being handled improperly and by untrained workers without any safety gears, leading to increased virus transmission among workers. These wastes are sometimes dumped in unauthorized and unprotected areas, affecting human health, and increasing the COVID-19 transmission rate. Therefore, a proper

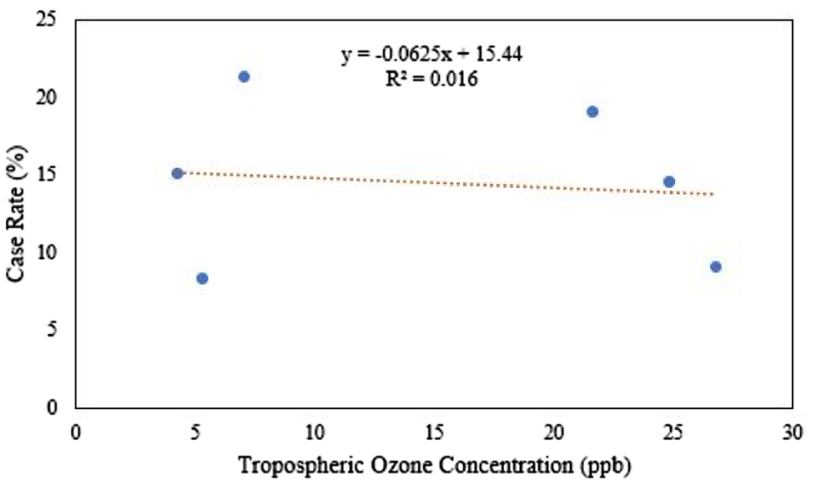

(b)

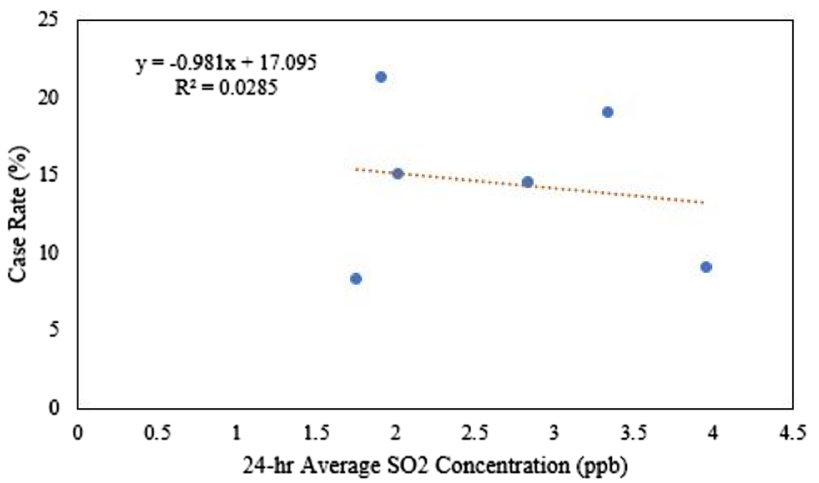

(d)

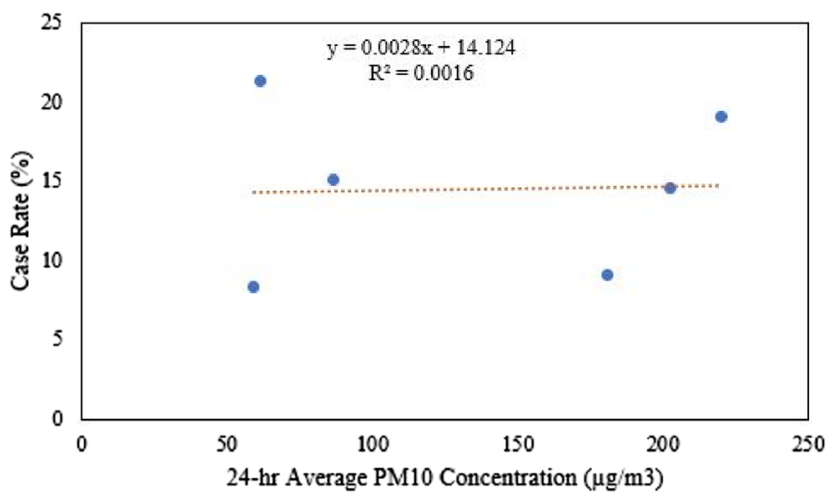

(f)

concentration (ppb), e $24 \mathrm{~h}$ average PM2.5 concentration $\left(\mu \mathrm{g} / \mathrm{m}^{3}\right)$, and f $24 \mathrm{~h}$ average PM10 concentration $\left(\mu \mathrm{g} / \mathrm{m}^{3}\right)$, obtained from CAMS over Rajshahi city, Bangladesh

waste management strategy is necessary to overcome this situation. High environmental noise is detrimental to human health, and can be responsible for cardiac arrest, hypertension, and other diseases (Mostafa et al. 2021; Muzet 2007; Zambrano-Monserrate et al. 2020). During the lockdown period, many industries and transportation were not in operation. Thus, considerable reduction of noise was observed. Similar cases were observed in different countries during the lockdown (Ahramonline 2020; Masrawy 2020). 
Table 7 Summary of intercepts, slopes, coefficients of determination, and Pearson ' $r$ ' for different pollutants and meteorological variables from regression analysis

\begin{tabular}{lrrll}
\hline Pollutants & Intercept & \multicolumn{1}{l}{ Slope } & $\begin{array}{l}\text { Coefficient of determi- } \\
\text { nation }\left(R^{2}\right)\end{array}$ & Pearson ' $r$ ' \\
\hline $\mathrm{NO}_{2}$ & 19.5740 & -0.4256 & 0.0842 & 0.2901 \\
$\mathrm{O}_{3}$ & 15.4400 & -0.0625 & 0.0160 & 0.1264 \\
$\mathrm{CO}$ & 16.5790 & -2.5855 & 0.0566 & 0.2378 \\
$\mathrm{PM}_{2.5}$ & 15.9890 & -0.0259 & 0.0292 & 0.1709 \\
$\mathrm{PM}_{10}$ & 14.1240 & 0.0028 & 0.0016 & 0.0397 \\
$\mathrm{SO}_{2}$ & 17.0950 & -0.9810 & 0.0285 & 0.1687 \\
Average temperature & -17.9660 & 0.3839 & 0.0646 & 0.2542 \\
Dew-point temperature & -45.8410 & 0.7884 & 0.5323 & 0.7296 \\
Average wind speed & 13.2420 & 0.4930 & 0.0098 & 0.0988 \\
Precipitation & 13.9790 & 0.9968 & 0.0138 & 0.1176 \\
\hline
\end{tabular}

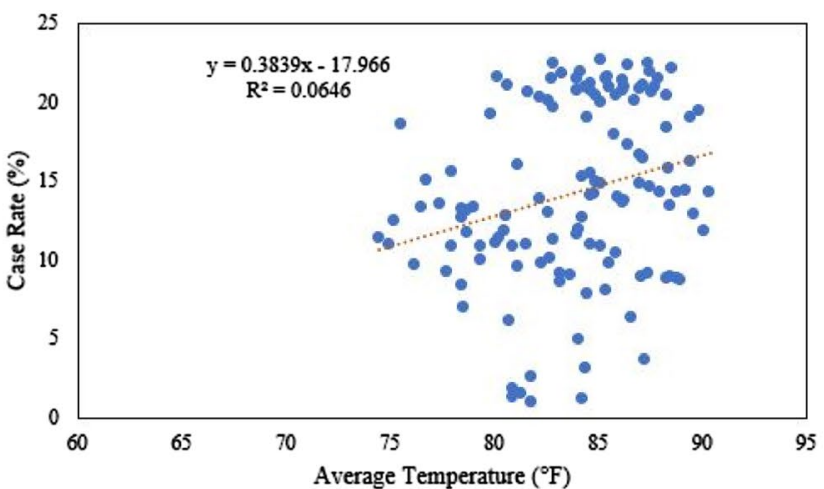

(a)

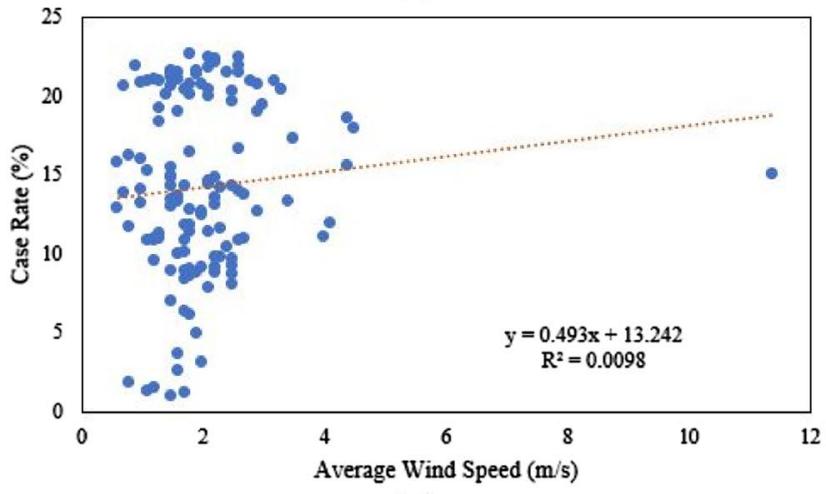

(c)

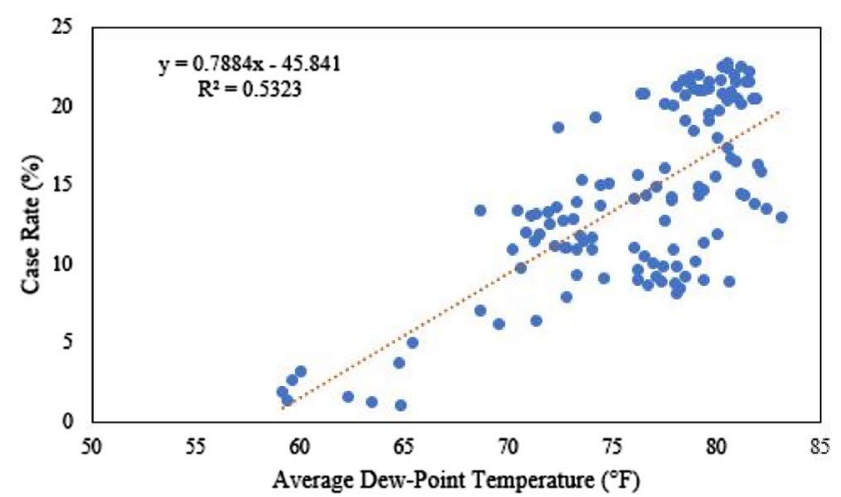

(b)

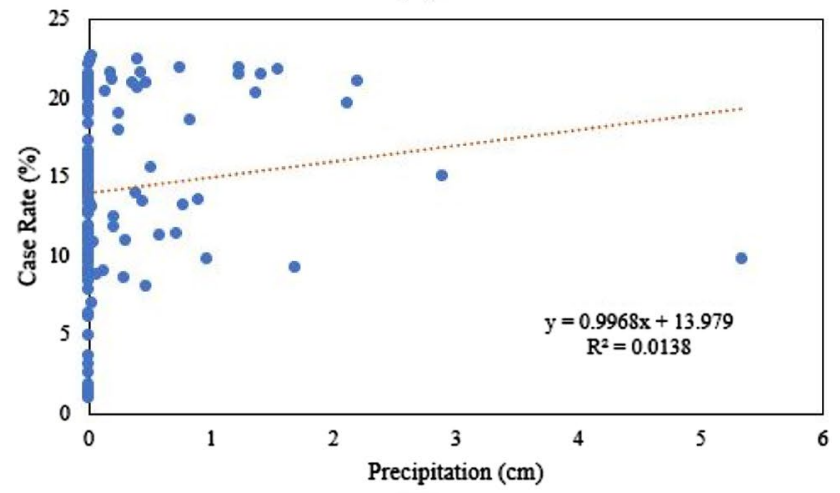

(d)

Fig. 6 Correlation between COVID-19 case rates and meteorological phenomena: (a) average temperature $\left({ }^{\circ} \mathrm{F}\right)$, b dew-point temperature $\left({ }^{\circ} \mathrm{F}\right)$, c average wind speed $(\mathrm{m} / \mathrm{s})$, and $\mathbf{d}$ precipitation $(\mathrm{cm})$ over Rajshahi city, Bangladesh

\section{Conclusions}

This study found that air quality and other socio-economic factors have been greatly affected by COVID-19 lockdown period. These other factors included the economy, waste management scenario, environmental noise, etc. Both positive and negative impacts of the viral spread containment actions taken by the government have been observed. Negative impacts of the lockdown included economic losses, educational vacation for prolonged periods, difficulties in handling municipal and medical wastes, etc.

Conversely, positive impacts have been observed for environmental pollution, especially air pollution. Considerable improvements of different air quality parameters, such as $\mathrm{NO}_{2}, \mathrm{O}_{3}, \mathrm{CO}, \mathrm{SO}_{2}, \mathrm{PM}_{2.5}, \mathrm{PM}_{10}$, AOD, and black carbon 
emissions, have been observed during lockdown period. To assess changes in these variables, satellite data and CAMS data from Rajshahi were used. However, the air quality improvements were not sustained with substantial increases in all the air pollutants being observed in the post-lockdown period. The lockdown period resulted in large economic crises in Bangladesh. Thus, the government was unable to invest more for clean air development and the gains during the lockdown were lost. Statistical analyses showed statistically significant differences in the measured variables among the lockdown, pre-lockdown, and post-lockdown stages.

Relationships between daily confirmed case rates and the different air pollutants were estimated using linear regression. $\mathrm{PM}_{10}$ had a weak positive association with case rates, while the others showed weak negative associations. Variations of different meteorological variables, such as average temperature, dew-point temperature, average wind speed, and precipitation with daily COVID-19 case rates, were also presented in this study. All the meteorological variables showed weak positive correlations with the COVID case rates. A drastic deterioration of air quality in Rajshahi city was observed in post-lockdown stage. Thus, it is recommended that the government takes necessary steps and applies strict laws to protect the environment, and provides a balance between economic growth and a sustainable environment. It is expected that this study could serve as the basis for future research of the assessment of environmental and meteorological behavior in relation to COVID-19 for other parts of the world.

Acknowledgements Authors would like to acknowledge the Department of Mechanical Engineering, Rajshahi University of Engineering \& Technology, Bangladesh for supporting the research work. The authors are also thankful to the Ministry of Environment, Forests and Climate Change, Bangladesh for providing the air quality data.

Author Contributions All the authors have contributed substantially to the work reported. All authors have read and agreed to the published version of the manuscript. MMA: conceptualization, literature review, writing (original draft), writing (review and editing), and visualization. MEH: conceptualization, data analysis, writing (original draft), writing (review and editing), and supervision. SR: data curation and writing (review and editing). PKR: writing (original draft) and data curation. FA: conceptualization, data analysis, and writing (review and editing). MMR: conceptualization, data analysis, and writing (review and editing). MMR: data analysis and writing (review and editing). PKH: conceptualization, data analysis, supervision, and writing (review and editing).

Funding This research received no external funding.

Data Availability The data that support the findings of this study are available from the corresponding author upon reasonable request.

\section{Declarations}

Conflicts of Interest The authors declare no conflict of interest.

\section{References}

Abnett K (2020) China sees post-lockdown rise in air pollution: study https://www.reuters.com/article/us-health-coronavirus-chinapollution/china-sees-post-lockdown-rise-in-air-pollution-studyidUSKBN22U09F

Ackermann-Liebrich U, Leuenberger P, Schwartz J, Schindler C, Monn C, Bolognini G, Bongard J, Brändli O, Domenighetti G, Elsasser S (1997) Lung function and long term exposure to air pollutants in Switzerland. Study on air pollution and lung diseases in adults (SAPALDIA) team. Am J Respir Crit Care Med 155(1):122-129

Ahramonline (2020) As lockdown clears the air, Cairo looks to keep pollution low https://english.ahram.org.eg/NewsContent/1/64/ 369929/Egypt/Politics-/As-lockdown-clears-the-air,-Cairo-looksto-keep-po.aspx

Akanda AAM, Ahmed R (2020) How successful Bangladesh is in controlling the coronavirus pandemic? Bull Natl Res Centre. https:// doi.org/10.1186/s42269-020-00451-4

Akbostancı E, Türüt-Aşık S, Tunç Gİ (2009) The relationship between income and environment in Turkey: is there an environmental Kuznets curve? Energy Policy 37(3):861-867

Banglapedia (2021) Rajshahi District http://en.banglapedia.org/index. php/Rajshahi_District

Banna MHA, Sayeed A, Kundu S, Christopher E, Hasan MT, Begum MR, Kormoker T, Dola STI, Hassan MM, Chowdhury S, Khan MSI (2020) The impact of the COVID-19 pandemic on the mental health of the adult population in Bangladesh: a nationwide crosssectional study. Int J Environ Health Res. https://doi.org/10.1080/ 09603123.2020.1802409

Bao R, Zhang A (2020) Does lockdown reduce air pollution? Evidence from 44 cities in northern China. Sci Total Environ 731:139052

Bashir MF, Ma B, Komal B, Bashir MA, Tan D, Bashir M (2020) Correlation between climate indicators and COVID-19 pandemic in New York, USA. Sci Total Environ 728:138835

Begum BA, Nasiruddin M, Scott R, Sivertsen B, Hopke PK (2014) Identification and apportionment of sources from air particulate matter at urban environments in Bangladesh. Br J Appl Sci Technol 4:3930-3955

Begum M, Farid MS, Alam MJ, Barua S (2020) COVID-19 and Bangladesh: socio-economic analysis towards the future correspondence. Asian J Agric Ext Econ Sociol 38:143-155

Bherwani H, Anjum S, Kumar S, Gautam S, Gupta A, Kumbhare H, Anshul A, Kumar R (2021) Understanding COVID-19 transmission through Bayesian probabilistic modeling and GIS-based Voronoi approach: a policy perspective. Environ Dev Sustainability 23(4):5846-5864

Blumenthal I (2001) Carbon monoxide poisoning. J R Soc Med 94(6):270-272

Brunekreef B, Holgate ST (2002) Air Pollution and Health. Lancet 360(9341):1233-1242

Burnett RT, Stieb D, Brook JR, Cakmak S, Dales R, Raizenne M, Vincent R, Dann T (2004) Associations between short-term changes in nitrogen dioxide and mortality in Canadian cities. Arch Environ Health: Int J 59(5):228-236

CASE (2021) Clean air \& sustainable environment, ministry of environment \& forest http://case.doe.gov.bd/index.php?option=com content \&view $=$ article $\&$ id $=5 \&$ Itemid $=9$

Cheng M, Jiang H, Guo Z (2012) Evaluation of long-term tropospheric $\mathrm{NO}_{2}$ columns and the effect of different ecosystem in Yangtze River Delta. Procedia Environ Sci 13:1045-1056

Collivignarelli MC, Abbà A, Bertanza G, Pedrazzani R, Ricciardi P, Miino MC (2020) Lockdown for CoViD-2019 in Milan: what are the effects on air quality? Sci Total Environ 732:139280

Corona_Info_Bangladesh. (2021). Coronavirus Disease 2019 (COVID19) Information Bangladesh https://corona.gov.bd/ 
Dantas G, Siciliano B, França BB, da Silva CM, Arbilla G (2020) The impact of COVID-19 partial lockdown on the air quality of the city of Rio de Janeiro, Brazil. Sci Total Environ 729:139085

DGHS (2021) Directorate General of Health Services, Bangladesh http://dashboard.dghs.gov.bd/webportal/pages/covid19.php

Dhaka-Tribune (2020) Hand sanitizer, mask prices skyrocketing https:// www/dhakatribune.com/business/2020/03/09/hand-sanitizermask-prices-skyrocketing

Dunn OJ (1964) Multiple comparisons using rank sums. Technometrics 6:241-252

Dutheil F, Baker JS, Navel V (2020) COVID-19 as a factor influencing air pollution? Environ Pollut 263:114466

Engel-Cox JA, Hoff RM, Haymet A (2004) Recommendations on the use of satellite remote-sensing data for urban air quality. J Air Waste Manag Assoc 54(11):1360-1371

ESRL (2021) Global monitoring laboratory-global radiation and aerosols https://www.esrl.noaa.gov/gmd/grad/surfrad/aod/

Fernandes N (2020) Economic effects of coronavirus outbreak (COVID-19) on the world economy. Available at SSRN 3557504

Gautam S (2020) COVID-19: air pollution remains low as people stay at home. Air Qual Atmos Health 13:853-857

GIOVANNI (2021) National Aeronautics and Space Administration (NASA) https://giovanni.gsfc.nasa.gov/giovanni/

Grossman GM, Krueger AB (1991) Environmental impacts of a North American free trade agreement. National Bureau of economic research Cambridge, Mass, USA

Holz O, Jorres RA, Timm P, Mucke M, Richter K, Koschyk S, Magnussen H (1999) Ozone-induced airway inflammatory changes differ between individuals and are reproducible. Am J Respir Crit Care Med 159(3):776-784

Hossain I, Mullick AR, Khan MH, Ahmad SA, Rahman MS, Aktaruzzaman M (2020) Epidemiology of coronavirus disease: past, present, future prospects and its journey towards Bangladesh. Epidemiology 25(06):2517

Hridoy AE, Mohiman MA, Tusher SMSH, Nowraj SZA, Rahman MA (2021) Impact of meteorological parameters on COVID-19 transmission in Bangladesh: a spatiotemporal approach. Theoret Appl Climatol 144(1):273-285

IEDCR (2021) Institute of epidemiology, disease control and research (IEDCR) https://www.iedcr.org/

Islam ARMT, Hasanuzzaman M, Shammi M, Salam R, Bodrud-Doza M, Rahman MM, Mannan MA, Huq S (2021a) Are meteorological factors enhancing COVID-19 transmission in Bangladesh? Novel findings from a compound poisson generalized linear modeling approach. Environ Sci Pollut Res 28(9):11245-11258

Islam MS, Rahman M, Tusher TR, Roy S, Razi MA (2021b) Assessing the relationship between COVID-19, air quality, and meteorological variables: a case study of Dhaka City in Bangladesh. Aerosol Air Qual Res 21(6):200609

Islam MS, Tusher TR, Roy S, Rahman M (2021c) Impacts of nationwide lockdown due to COVID-19 outbreak on air quality in Bangladesh: a spatiotemporal analysis. Air Qual Atmos Health 14(3):351-363

Jiang M, Kim E, Woo Y (2020) The relationship between economic growth and air pollution - a regional comparison between China and South Korea. Int J Env Res Public Health 17(8):2761

Kafieh R, Arian R, Saeedizadeh N, Minaee S, Amini Z, Yadav SK, Vaezi A, Rezaei N, Javanmard SH (2020) COVID-19 in Iran: a deeper look into the future. MedRxiv. https://doi.org/10.1101/ 2020.04.24.20078477

Khaled, S. M. S. (2020). The way Covid-19 is affecting Bangladesh economy https://www.theindependentbd.com/post/237519

Kumar V, Singh SB, Singh S (2020) COVID-19: environment concern and impact of Indian medicinal system. J Environ Chem Eng $8(5): 104144$
Lai C-C, Shih T-P, Ko W-C, Tang H-J, Hsueh P-R (2020) Severe acute respiratory syndrome coronavirus 2 (SARS-CoV-2) and coronavirus disease-2019 (COVID-19): the epidemic and the challenges. Int J Antimicrob Agents 55(3):105924

Liu J, Zhou J, Yao J, Zhang X, Li L, Xu X, He X, Wang B, Fu S, Niu T (2020) Impact of meteorological factors on the COVID19 transmission: a multi-city study in China. Sci Total Environ 726:138513

Mahato S, Pal S, Ghosh KG (2020) Effect of lockdown amid COVID19 pandemic on air quality of the megacity Delhi, India. Sci Total Environ 730:139086

Mahmood SAI (2011) Air pollution kills 15,000 Bangladeshis each year: the role of public administration and governments integrity. J Public Adm Policy Res 3(5):129-140

Martelletti L, Martelletti P (2020) Air pollution and the novel Covid19 disease: a putative disease risk factor. SN Compr Clin Med 2(4):383-387

Masrawy (2020) Environment minister: air pollution decreased by $45 \%$ during the corona crisis and the curfew decision https://www. masrawy.com/news/news-videos/details/2020/7/14/1831478/

Masum MH, Mohammad S, Rahman R, Pal SK (2020) Assessment of ambient air quality in major cities of Bangladesh. Parana J Sci Educ (PJSE) 6(5):61-67

McDonnell WF, Abbey DE, Nishino N, Lebowitz MD (1999) Longterm ambient ozone concentration and the incidence of asthma in nonsmoking adults: the AHSMOG Study. Environ Res 80(2):110-121

McKibbin WJ, FernandoR (2020) The global macroeconomic impacts of COVID-19: seven scenarios https://www.brookings.edu/resea $\mathrm{rch} /$ the-global-macroeconomic-impacts-of-covid-19-seven-scena rios/

Metya A, Dagupta P, Halder S, Chakraborty S, Tiwari YK (2020) COVID-19 lockdowns improve air quality in the South-East Asian regions, as seen by the remote sensing satellites. Aerosol Air Qual Res 20(8):1772-1782

Ministry of Environment, F. a. C. C., Bangladesh (MEFC) (2020) Monthly air quality monitoring report (July 2020). http://case. doe.gov.bd/index.php?option=com_content\&view=article\&id= $5 \&$ Itemid $=9$

Mishra M, Kulshrestha U (2021) A brief review on changes in air pollution scenario over south asia during COVID-19 lockdown. Aerosol Air Qual Res 21:200541

MOE (2021) Ministry of education, Dhaka, Bangladesh https:// moedu.gov.bd/

Mostafa MK, Gamal G, Wafiq A (2021) The impact of COVID 19 on air pollution levels and other environmental indicators-a case study of Egypt. J Environ Manag 277:111496

Muhammad S, Long X, Salman M (2020) COVID-19 pandemic and environmental pollution: a blessing in disguise? Sci Total Environ $728: 138820$

Muzet A (2007) Environmental noise, sleep and health. Sleep Med Rev 11(2):135-142

Nakada LYK, Urban RC (2020) COVID-19 pandemic: impacts on the air quality during the partial lockdown in São Paulo state, Brazil. Sci Total Environ 730:139087

Nile F (2020) Egyptians increase their online shopping by $940 \%$ amid COVID-19 pandemic https://nilefm.com/digest/article/5743/ egyptians-increasingly-turn-to-e-commerce-to-avoid-crowds

NOAA (2021) National Centers for Environmental Information (NCEI) https://www.ncei.noaa.gov/access/search/data-search/ global-summary-of-the-day

Ogen Y (2020) Assessing nitrogen dioxide $\left(\mathrm{NO}_{2}\right)$ levels as a contributing factor to coronavirus (COVID-19) fatality. Sci Total Environ 726:138605 
Ommi A, Emami F, Zíková N, Hopke PK, Begum BA (2017) Trajectory-based models and remote sensing for biomass burning assessment in Bangladesh. Aerosol Air Qual Res 17:465-475

Ozcan B, Tzeremes PG, Tzeremes NG (2020) Energy consumption, economic growth and environmental degradation in OECD countries. Econ Model 84:203-213

Panayotou T (1993) Empirical tests and policy analysis of environmental degradation at different stages of economic development. ILO Working Papers 992927783402676

Pandey JS, Kumar R, Devotta S (2005) Health risks of $\mathrm{NO}_{2}$, SPM and $\mathrm{SO}_{2}$ in Delhi (India). Atmos Environ 39(36):6868-6874

Panella M, Tommasini V, Binotti M, Palin L, Bona G (2000) Monitoring nitrogen dioxide and its effects on asthmatic patients: two different strategies compared. Environ Monit Assess 63(3):447-458

Pavel MRS, Salam A, Yesmin M, Ahsan N, Zaman SU, Jeba F (2020) Impact and correlation of air quality and climate variables with COVID-19 morbidity and mortality in Dhaka, Bangladesh. medRxiv. https://doi.org/10.1101/2020.09.12.20193086

Pedrosa RH (2020) The dynamics of Covid-19: weather, demographics and infection timeline. MedRxiv. https://doi.org/10.1101/2020.04. 21.20074450

Pérez-Martínez PJ, Miranda RM, Nogueira T, Guardani ML, Fornaro A, Ynoue R, Andrade MF (2014) Emission factors of air pollutants from vehicles measured inside road tunnels in São Paulo: case study comparison. Int J Environ Sci Technol 11(8):2155-2168

Qin Y, Tonnesen G, Wang Z (2004) Weekend/weekday differences of ozone, NOx, CO, VOCs, $\mathrm{PM}_{10}$ and the light scatter during ozone season in southern California. Atmos Environ 38(19):3069-3087

Rahman MM, Bodrud-Doza M, Griffiths MD, Mamun MA (2020) Biomedical waste amid COVID-19: perspectives from Bangladesh. Lancet Glob Health 8(10):e1262

Rahman MM, Begum BA, Hopke PK, Nahar K, Newman J, Thurston GD (2021a) Cardiovascular morbidity and mortality associations with biomass-and fossil-fuel-combustion fine-particulate-matter exposures in Dhaka, Bangladesh. Int J Epidemiol 50:1172

Rahman MM, Nahar K Begum BA, Hopke PK, Thurston GD (2021b) Respiratory emergency department visits associations with exposures to PM2. 5 mass, constituents, and sources in Dhaka, Bangladesh air pollution. Ann Am Thorac Soc(ja). https://doi. org/10.1513/AnnalsATS.202103-252OC

Richter A, Burrows J (2002) Tropospheric $\mathrm{NO}_{2}$ from GOME measurements. Adv Space Res 29(11):1673-1683

Santoso M, Hopke PK, Permadi DA, Damastuti E, Lestiani DD, Kurniawati S, Khoerotunnisya D, Sukir SK (2021) Multiple air quality monitoring evidence of the impacts of large-scale social restrictions during the COVID-19 pandemic in Jakarta, Indonesia. Aerosol Air Qual Res 21:200645

Schelegle ES, Eldridge MW, Cross CE, Walby WF, Adams WC (2001) Differential effects of airway anesthesia on ozoneinduced pulmonary responses in human subjects. Am J Respir Crit Care Med 163(5):1121-1127

Seinfeld JH, Pandis SN (2016) Atmospheric chemistry and physics: from air pollution to climate change, 3rd edn. John Wiley \& Sons, Hoboken, NJ

Shammi M, Bodrud-Doza M, Islam ARMT, Rahman MM (2021) Strategic assessment of COVID-19 pandemic in Bangladesh: comparative lockdown scenario analysis, public perception, and management for sustainability. Environ Dev Sustain 23(4):6148-6191

Sharma S, Zhang M, Gao J, Zhang H, Kota SH (2020) Effect of restricted emissions during COVID-19 on air quality in India. Sci Total Environ 728:138878
Sicard P, De Marco A, Agathokleous E, Feng Z, Xu X, Paoletti E, Rodriguez JJD, Calatayud V (2020) Amplified ozone pollution in cities during the COVID-19 lockdown. Sci Total Environ $735: 139542$

Smith B, Nitschke M, Pilotto L, Ruffin R, Pisaniello D, Willson K (2000) Health effects of daily indoor nitrogen dioxide exposure in people with asthma. Eur Respir J 16(5):879-885

Sohrabi C, Alsafi Z, O'neill N, Khan M, Kerwan A, Al-Jabir A, Iosifidis C, Agha R (2020) World Health Organization declares global emergency: a review of the 2019 novel coronavirus (COVID-19). Int J Surg 76:71-76

Stieb DM, Judek S, Burnett RT (2002) Meta-analysis of time-series studies of air pollution and mortality: effects of gases and particles and the influence of cause of death, age, and season. J Air Waste Manag Assoc 52(4):470-484

TOAB (2020) Impacts on Bangladesh tourism and TOAB due to COVID-19 https://m.theindependentbd.com/online/travel-touri $\mathrm{sm}$

Tobías A, Carnerero C, Reche C, Massagué J, Via M, Minguillón MC, Alastuey A, Querol X (2020) Changes in air quality during the lockdown in Barcelona (Spain) one month into the SARSCoV-2 epidemic. Sci Total Environ 726:138540

Torkmahalleh MA, Akhmetvaliyeva Z, Darvishi Omran A, Darvish Omran F, Kazemitabar M, Naseri M, Naseri M, Sharifi H, Malekipirbazari M, Kwasi Adotey, E (2021) Global air quality and covid-19 pandemic: do we breathe cleaner air?

Tosepu R, Gunawan J, Effendy DS, Lestari H, Bahar H, Asfian P (2020) Correlation between weather and Covid-19 pandemic in Jakarta, Indonesia. Sci Total Environ 725:138436

Veefkind P, Van Oss R, Eskes H, Borowiak A, Dentner F, Wilson J (2007) The applicability of remote sensing in the field of air pollution. Institute for Environment and Sustainability, Italy, p 59

Verma RL, Kamyotra JS (2021) Impacts of COVID-19 on air quality in India. Aerosol Air Qual Res 21:19

Wang Q, Su M (2020) A preliminary assessment of the impact of COVID-19 on environment-a case study of China. Sci Total Environ 728:138915

Wang Q, Zeng Q, Tao J, Sun L, Zhang L, Gu T, Wang Z, Chen L (2019) Estimating PM2. 5 concentrations based on MODIS AOD and NAQPMS data over Beijing-Tianjin-Hebei. Sensors 19(5):1207

WHO (2020) Situation report-51, coronavirus disease 2019 (COVID-19)

WHO (2021) COVID-19 weekly epidemiological update $22 \mathrm{https}: / /$ www.who.int/docs/default-source/coronaviruse/situation-reports/ weekly_epidemiological_update_22.pdf

World_Bank (2019) International Tourism, number of arrivals-East Asia \& Pacific. https://data.worldbank.org/indicator/ST.INT. ARVL?end $=2017 \&$ locations $=$ Z4\&name_desc $=$ false \&start $=$ $2017 \&$ type $=$ shaded $\&$ view $=$ map $\&$ year $=2018$

Worldometer (2021) Bangladesh Coronavirus Updates https://www. worldometers.info/coronavirus/country/bangladesh/

$\mathrm{Xu}$ B, Luo L, Lin B (2016) A dynamic analysis of air pollution emissions in China: Evidence from nonparametric additive regression models. Ecol Indicators 63:346-358

Zambrano-Monserrate MA, Ruano MA, Sanchez-Alcalde L (2020) Indirect effects of COVID-19 on the environment. Sci Total Environ $728: 138813$

Zhu Y, Xie J, Huang F, Cao L (2020) Association between short-term exposure to air pollution and COVID-19 infection: evidence from China. Sci Total Environ 727:138704 